Keywords: Climate Change, Watershed Runoff, BASINS, HSPF

Retention: Permanent

\title{
EFFECTS OF CLIMATE CHANGE ON WATERSHED RUNOFF FLOW UPPER COOSA RIVER BASIN UPSTREAM FROM PLANT HAMMOND
}

Kuo-Fu Chen

October 24, 2011

Savannah River National Laboratory

Savannah River Nuclear Solutions

Aiken, SC 29808

Prepared for the U.S. Department of Energy Under

Contract Number DE-AC09-08SR22470 
SRNL-STI-2011-00651

Revision 0

\section{DISCLAIMER}

This work was prepared under an agreement with and funded by the U.S. Government. Neither the U. S. Government or its employees, nor any of its contractors, subcontractors or their employees, makes any express or implied:

1. warranty or assumes any legal liability for the accuracy, completeness, or for the use or results of such use of any information, product, or process disclosed; or

2. representation that such use or results of such use would not infringe privately owned rights; or

3. endorsement or recommendation of any specifically identified commercial product, process, or service.

Any views and opinions of authors expressed in this work do not necessarily state or reflect those of the United States Government, or its contractors, or subcontractors.

\section{Printed in the United States of America}

Prepared for

U.S. Department of Energy 
Keywords: Climate Change, Watershed Runoff, BASINS, HSPF

Retention: Permanent

\section{EFFECTS OF CLIMATE CHANGE ON WATERSHED RUNOFF FLOW UPPER COOSA RIVER BASIN UPSTREAM FROM PLANT HAMMOND}

Kuo-Fu Chen

October 24, 2011

Savannah River National Laboratory

Savannah River Nuclear Solutions

Savannah River Site

Aiken, SC 29808 


\section{REVIEWS AND APPROVALS}

AUTHOR:

Kuo-Fu Chen, Atmospheric Technologies Group

Date

TECHNICAL REVIEW:

Robert L. Buckley, Atmospheric Technologies Group

Date

APPROVAL:

Charles H. Hunter, Manager

Date

Atmospheric Technologies Group

Lori M. Chandler, Manager

Date

Nonproliferation Technologies Section 
SRNL-STI-2011-00651

Revision 0

\begin{abstract}
The ability of water managers to maintain adequate supplies in the coming decades depends on future weather conditions, as climate change has the potential to reduce stream flows from their current values due to potentially less precipitation and higher temperatures, and possibly rendering them unable to meet demand. The upper Coosa River basin, located in northwest Georgia, plays an important role in supplying water for industry and domestic use in northern Georgia, and has been involved in water disputes in recent times. The seven-day ten-year low flow (7Q10 flow) is the lowest average flow for seven consecutive days that has an average recurrence interval of 10 years. The $7 \mathrm{Q} 10$ flow is statistically derived from the observed historical flow data, and represents the low flow (drought) condition for a basin. The upper Coosa River basin also supplies cooling water for the 935MW coal-fired Hammond plant, which draws about $65 \%$ of the $7 \mathrm{Q} 10$ flow of the upper Coosa River to dissipate waste heat. The water is drawn through once and returned to the river directly from the generator (i.e., no cooling tower is used). Record low flows in 2007 led to use of portable cooling towers to meet temperature limits. Disruption of the Plant Hammond operation may trigger closure of area industrial facilities (e.g. paper mill). The population in Georgia is expected to double from 9 million to 18 million residents in the next 25 years, mostly in the metropolitan Atlanta area. Therefore, there will be an even greater demand for potable water and for waste assimilation. Climate change in the form of persistent droughts (causing low flows) and high ambient temperatures create regulatory compliance challenges for Plant Hammond operating with a once-through cooling system. Therefore, the Upper Coosa River basin was selected to study the effect of potential future weather change on the watershed runoff flow.
\end{abstract}




\section{TABLE OF CONTENTS}

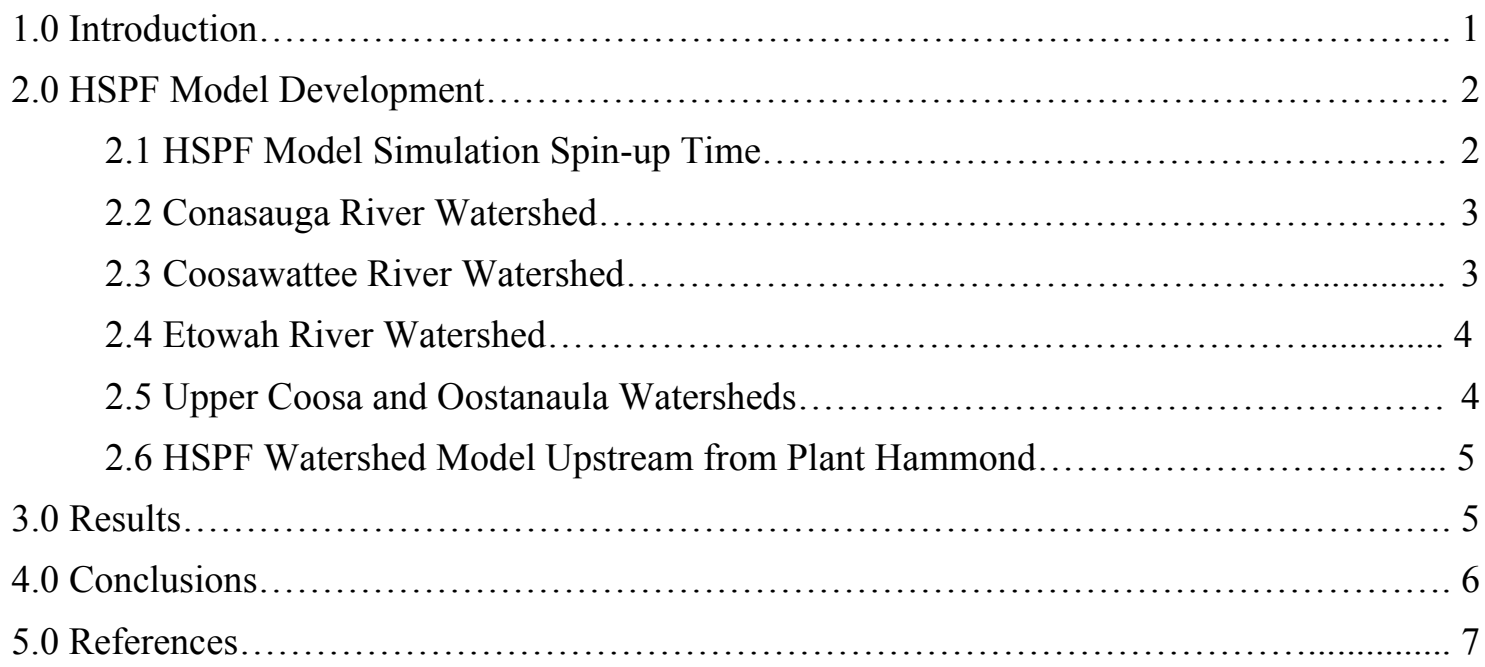




\section{LIST OF TABLES}

Table 1. Comparison of Conasauga River Watershed Outlet Flow Volume at USGS02387000.

Table 2. Comparison of Coosawattee River Watershed Outlet Flow Volume at USGS02383500. 9

Table 3. Comparison of Etowah River Watershed Outlet Flow Volume at USGS02396000... 10

Table 4. Comparison of Upper Coosa and Oostanaula Watershed Outlet Flow Volume at USGS02397000....................................................... 11

Table 5. Estimated 7Q10 Flow....................................................... 12 


\section{LIST OF FIGURES}

Figure 1. Watershed Upstream from Plant Hammond $\ldots \ldots \ldots \ldots \ldots \ldots \ldots \ldots \ldots \ldots \ldots \ldots \ldots \ldots \ldots$

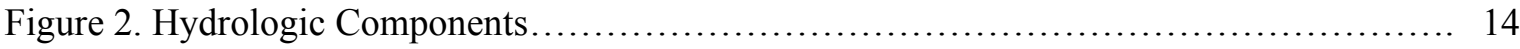

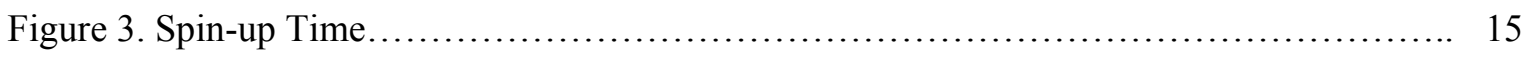

Figure 4. Modeled Conasauga Watershed Upstream from USGS02387000 Gage Station........ 16

Figure 5. Simulated and Observed Conasauga Watershed Flow Duration.................... 17

Figure 6. Simulated and Observed Conasauga Watershed Daily Mean Flow at USGS02387000 18

Figure 7. Modeled Coosawattee Watershed Upstream from USGS02383500 Gage Station..... 19

Figure 8. Simulated and Observed Coosawattee Watershed Flow Duration.................. 20

Figure 9. Simulated and Observed Conasauga Watershed Daily Mean Flow at USGS02387000 21

Figure 10. Modeled Etowah Watershed Upstream from USGS02396000 Gage Station.......... 22

Figure 11. Simulated and Observed Etowah Watershed Flow Duration........................ 23

Figure 12. Simulated and Observed Etowah Watershed Daily Mean Flow at USGS02396000_.. 24

Figure 13. Modeled Upper Coosa \& Oostanaula Watersheds Upstream from USGS02397000

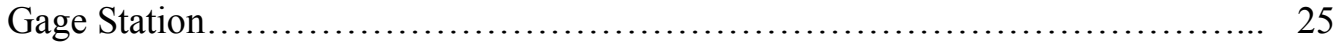

Figure 14. Simulated and Observed Upper Coosa and Oostanaula Watersheds Flow Duration... 26

Figure 15. Simulated and Observed Upper Coosa and Oostanaula Watersheds Daily Mean Flow at USGS02397000............................................. 27

Figure 16. Modeled Watershed Upstream from Plant Hammond........................... 28

Figure 17. Mean Monthly Flow................................................. 29

Figure 18. Comparison of Mean Monthly Flow (Downscaled) .......................... 30

Figure 19. Comparison of Mean Monthly Flow (Unscaled)............................. 31

Figure 20. Calculated Runoff Flow at Plant Hammond GISS ............................ 32

Figure 21. Calculated Runoff Flow at Plant Hammond CCC ........................... 33

Figure 22. Calculated Runoff Flow at Plant Hammond MRI........................... 34

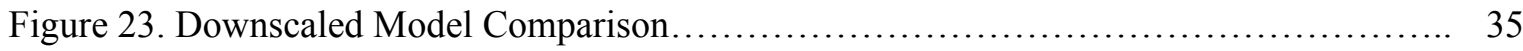

Figure 24. Unscaled Model Comparison............................................ 36

Figure 25. Seven-Day Low-Flow Frequency Curve for Coosa River Upstream from Plant

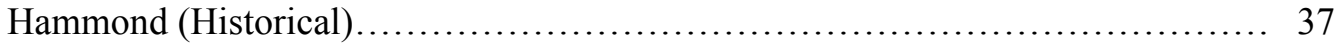

Figure 26. Seven-Day Low-Flow Frequency Curve for Coosa River Upstream from Plant Hammond. 
SRNL-STI-2011-00651

Revision 0

Blank Page

vii 
SRNL-STI-2011-00651

Revision 0

\subsection{INTRODUCTION}

The ability of water managers to maintain adequate supplies in the coming decades depends on future weather conditions, as climate change has the potential to reduce stream flows from their current values due to potentially less precipitation and higher temperatures, and possibly rendering them unable to meet demand. The upper Coosa River basin, located in northwest Georgia, plays an important role in supplying water for industry and domestic use in northern Georgia, and has been involved in water disputes in recent times (Joyner, 2011). The seven-day ten-year low flow (7Q10 flow) is the lowest average flow for seven consecutive days that has an average recurrence interval of 10 years. The 7Q10 flow is statistically derived from the observed historical flow data, and represents the low flow (drought) condition for a basin. The upper Coosa River basin also supplies cooling water for the 935MW coal-fired Hammond plant, which draws about $65 \%$ of the $7 \mathrm{Q} 10$ flow of the upper Coosa River to dissipate waste heat. The water is drawn through once and returned to the river directly from the generator (i.e., no cooling tower is used). Record low flows in 2007 led to use of portable cooling towers to meet temperature limits. Disruption of the Plant Hammond operation may trigger closure of area industrial facilities (e.g. paper mill). The population in Georgia is expected to double from 9 million to 18 million residents in the next 25 years, mostly in the metropolitan Atlanta area. Therefore, there will be an even greater demand for potable water and for waste assimilation. Climate change in the form of persistent droughts (causing low flows) and high ambient temperatures create regulatory compliance challenges for Plant Hammond operating with a once-through cooling system. Therefore, the Upper Coosa River basin was selected to study the effect of potential future weather change on the watershed runoff flow.

This report documents studies of the potential effect of future climate change on the Upper Coosa River basin watershed runoff. The process for this study is discussed in two reports. In the first report (Part 1), future weather conditions are predicted by using a statistical technique to downscale future climate produced by Global Climate Models (GCMs) to a regional/local area (Werth, 2011). This second part (Part 2) estimates the watershed runoff flow based on the future climate generated in Part 1. The Upper Coosa River in northwest Georgia includes the Conasauga, Coosawattee, Oostanaula and Etowah River watersheds, as shown in Fig. 1. The

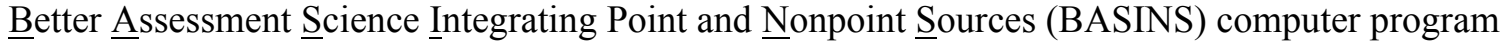
(U.S. EPA, 2007) was used to develop the watershed runoff model. BASINS integrates the Geographic Information System (GIS), data analysis modeling system to support watershedbased analyses. In this study, BASINS:

1) Downloads the digital elevation, national hydrography data, meteorological and stream flow data, as well as the soil and land data utilized in this study from various internet sources;

2) Delineates the watersheds; and

3) Generates input files for the watershed runoff model, HSPF (Hydrological Simulation Program - FORTRAN) (Bicknell et al., 2005).

The HSPF watershed runoff model has to be calibrated based on observed weather (i.e., precipitation, temperature and potential evapotranspiration) and stream flow data. The Coosawattee river is impounded by Carters Dam, forming Carters Lake which was completed in 1977, and the Etowah river is impounded by Allatoona Dam which was completed in 1950. The stream flows of the Coosawattee and Etowah rivers are influenced by the dam operations. 
Therefore, the Coosawattee and Etowah River watershed runoff models have to be developed by the data before dam construction occurred to avoid the artificial influence of the dam operation. There were no meteorological and observed flow data having the same time span common to all four watersheds before the construction of dams. Therefore, the HSPF runoff model was developed for each watershed separately. Then, the four derived HSPF runoff models were combined to form an HSPF runoff model to simulate the runoff flow upstream from Plant Hammond. The watershed parameters derived from the individual HSPF runoff model calibrations were kept the same in the combined HSPF runoff model.

\subsection{HSPF MODEL DEVELOPMENT}

HSPF is an EPA computer model that simulates the watershed hydrology and associated water quality for both conventional and toxic organic pollutants on pervious and impervious land surfaces and in streams and well-mixed impoundments. The HSPF model, summarized graphically in Fig. 2 (BASIN 4 Training Lecture 5 August, 2010), uses the time history of rainfall/snow melt, temperature and solar radiation as well as land surface characteristics (landuse patterns and land management practices) to simulate the interactions between the water and watershed environment. Those interactions are hydrologic components that include interception, depression storage, evapotranspiration, infiltration, surface storage, surface runoff, interflow, and groundwater flow. The result of this simulation is a time history of flow rate (hydrograph), as shown in Eq. 1 for water balance:

$\mathrm{R}=\mathrm{P}-\mathrm{E}-\mathrm{G}-\Delta \mathrm{S}$

Where:

$\mathrm{R}=$ Runoff

$\mathrm{P}=$ Precipitation

$\mathrm{E}=$ Evapotranspiration

$\mathrm{G}=$ Deep groundwater loss

$\Delta \mathrm{S}=$ Change in soil moisture storage

Various parameters are used to characterize the watershed hydrologic components. Those parameters were calibrated based on observed meteorological conditions and stream flows. This section presents the development of the HSPF watershed runoff models.

\section{1 $\underline{\text { HSPF Model Simulation Spin-up Time }}$}

The initial soil moisture profile affects the infiltration of precipitation and indirectly affects the available precipitation for watershed runoff. For most simulations, the initial soil moisture profile is unknown and is set in the program with an artificial default value. The effect of this initial soil condition on the simulation at later times decreases as the HSPF simulation duration increases. This section examines the sensitivity of HSPF model results to the initial soil conditions by 
SRNL-STI-2011-00651

Revision 0

varying the length of time in the initial model integration (i.e., "spin-up time"). Two cases for the Conasauga River watershed runoff flow were simulated with the same input conditions except the starting time. Case 1 was simulated from January 1, 1980 to December 31, 1990, and Case 2 was simulated from January 1, 1982 to December 31, 1990. Fig. 3 shows the relative differences of the simulated daily flow between these two cases and illustrates that the simulated daily flows for Case 2 are lower than Case 1 initially. However, the magnitude of the difference decreases as simulation time increases. After 23 months, both cases predict the same daily mean flows, as indicated by the zero difference. Thus, Fig. 3 shows that the memory effect of this initial soil condition decreases as simulation time increases. The default initial soil moisture profile for Case 2 indicates a very dry soil condition, as indicated by the large difference on January 1, 1982. Initially, Case 2 predicts that most of the precipitation is lost to infiltration and less precipitation is left for runoff flow, as indicated in Fig. 3. The soil condition was gradually adjusted and the memory effect of the initial soil condition is reduced in Case 2; as a result, the difference of the predicted daily flow between these two cases decreases as simulation time increases. After 23 months, the effect of the initial soil condition diminishes and the daily runoff flows predicted by both cases are equal (Fig. 3). Therefore, in this study, the results of the first two-years of the simulation are discarded.

\subsection{Conasauga River Watershed}

The Conasauga River originates in Murray County, Georgia and flows northward into Tennessee, where it flows briefly westward before turning back south and flowing into Murray County again. From there the Conasauga flows southwestward into Gordon County, where it converges with the Coosawattee River to form the Oostanaula River (GeorgiaInfo, 2011), as shown in Fig. 13. Fig. 4 shows the modeled Conasauga River watershed (679 square miles) upstream from the USGS gage station 02387000 (Latitude: $34^{\circ} 40^{\prime} 00^{\prime} \mathrm{N}$, Longitude: $84^{\circ} 55^{\prime} 42^{\prime}$ 'W). The red polygons in Fig. 4 represent the watershed model segments for the Conausaga River tributaries. The Conasauga River watershed runoff from January 1, 1980 to December 31, 1990 was simulated by the HSPF model using the input hourly precipitation and potential evapotranspiration data at the National Weather Service (NWS) station at Dalton, GA (GA092493; Latitude: 3445'19'N, Longitude: $\left.84^{\circ} 57^{\prime} 08^{\prime \prime} \mathrm{W}\right)$. The HSPF model parameters were adjusted based on trial and error with engineering judgment to have the simulated daily mean flow match the observed mean flow at the USGS gage station 02387000 . Table 1 presents the total flow volume through the USGS 02387000 location from 1982 to 1990 by month. Table 1 also shows that the differences between the observed and the simulated flow volume are less than 10\%. Fig. 5 presents the comparison of simulated and observed flow duration (note the log-probability scale), and Fig. 6 shows the simulated and observed hydrography.

\subsection{Coosawattee River Watershed}

The Coosawattee River is formed by the confluence of the Ellijay and Cartecay Rivers with their headwaters in the Blue Ridge Mountains. The river is impounded by Carters Dam, forming Carters Lake which was authorized by Congress in 1945, and completed in 1977 after 15 years of construction. Near New Echota, the Coosawattee meets the Conasauga River to form the Oostanaula River. Fig. 7 shows the modeled Coosawattee River watershed (828 square miles) upstream from the USGS gage station 02383500 (Latitude: $34^{\circ} 33^{\prime} 51^{\prime \prime N}$, Longitude: $84^{\circ} 49^{\prime} 59^{\prime \prime} \mathrm{W}$ ). The red polygons in Fig. 7 represent the watershed model segments for the Coosawattee River 
tributaries. The stream flow is influenced by the Carters Dam operation. Therefore, the Coosawattee River watershed runoff from January 1, 1950 to December 31, 1960 was simulated by the HSPF model to avoid the influence of the dam operation. The hourly meteorological data at the NWS stations at Ellijay, GA (GA093115; Latitude: 3441'26”N, Longitude: 84²9'07'W), at Fairmount, GA (GA093295; Latitude: $34^{\circ} 27^{\prime} 06^{\prime \prime N}$, Longitude: $84^{\circ} 42^{\prime} 31^{\prime \prime W}$ ) and at Jasper, GA (GA094648; Latitude: $34^{\circ} 29^{\prime} 45^{\prime \prime} \mathrm{N}$, Longitude: $84^{\circ} 27^{\prime} 33^{\prime \prime} \mathrm{W}$ ) were used in the simulation. The NWS Ellijay, GA and Fairmount, GA had only precipitation data. Therefore, the potential evapotranspiration data from the NWS Jasper, GA were used in model calibration. The HSPF model parameters were adjusted to have the simulated daily mean flow match the observed daily mean flow at the USGS gage station 02383500 . Table 2 presents the total flow volume through the USGS 02383500 location from 1952 to 1960 by month. Table 2 also shows that the differences between the observed and the simulated flow volume are less than $10 \%$. Fig. 8 presents the comparison of simulated and observed flow duration, and Fig. 9 shows the simulated and observed hydrography.

\subsection{Etowah River Watershed}

The Etowah River, beginning at Hightower Gap along the Appalachian Trail (about 15 miles northwest of Dahlonega) flows west-southwest through Canton, Georgia, and forms Lake Allatoona. From the dam at the lake, it flows past Cartersville and then to Rome where it meets the Oostanaula forming the Coosa River. The Allatoona project was authorized under the Flood Control Acts (FCAs) of August 18, 1941. Construction of the dam occurred in late 1940 and was in full operation by January 1950. Fig. 10 shows the modeled Etowah River watershed (1636 square miles) upstream from the USGS gage station 02396000 (Latitude: $34^{\circ} 15^{\prime} 26^{\prime \prime} \mathrm{N}$, Longitude: $85^{\circ} 09^{\prime} 30^{\prime \prime} \mathrm{W}$ ). The red polygons in Fig. 10 represent the watershed model segments for the Etowah River tributaries. The stream flow is influenced by the Allatoona Dam operation. Therefore, the Etowah River watershed runoff from January 1, 1935 to December 31, 1945 was simulated by the HSPF model to avoid the influence of the dam operation. The hourly precipitation and potential evapotranspiration data at the NWS station at Dahlonega, GA (GA092475; Latitude: 34³1'43”N, Longitude: 8400'17'W) and at Rome, GA (GA097600; Latitude: $34^{\circ} 14^{\prime} 43^{\prime \prime} \mathrm{N}$, Longitude: $85^{\circ} 09^{\prime} 05^{\prime \prime} \mathrm{W}$ ) were used in the simulation. The HSPF model parameters were adjusted to have the simulated daily mean flow match the observed daily mean flow at the USGS gage station 02396000 . Table 3 presents the total flow volume through the USGS 02396000 location from 1941 to 1945 by month. The data from 1941 to 1945 are used in this calibration because no observed flow data from 1935 to 1940 were available. Table 3 also shows that the differences between the observed and the simulated flow volume are less than 10\%. Fig. 11 presents the comparison of simulated and observed flow duration, and Fig. 12 shows the simulated and observed hydrography.

\subsection{Upper Coosa and Oostanaula Watersheds}

The Conasauga and Coosawattee Rivers converge to form the Oostanaula River near the New Echota historic site. The Etowah River merges with the Oostanaula River at Rome, GA to form the Coosa River, as shown in Fig. 13. Therefore, the HSPF runoff model for the Oostanaula and Upper Coosa watershed differs from the runoff model discussed above. In addition to precipitation, the Oostanaula and Upper Coosa watershed has three external flow sources, i.e., Conasauga, Coosawattee, and Etowah Rivers. The red polygons in Fig. 13 represent the 
watershed model segments for the Upper Coosa River and the Oostanaula River tributaries. The hourly precipitation and potential evapotranspiration data were from the NWS station at Calhoun, GA (GA091474; Latitude: 34²9'00”N, Longitude: 8458'00”W) and the NWS Rome, GA. The inlet flows from the Conasauga, Coosawattee and Etowah Rivers to the Oostanaula and Upper Coosa watershed were obtained from the USGS gage stations 02387000, 02383500, and 02396000, respectively. The Oostanaula River and Upper Coosa watershed runoff from January 1, 1970 to December 31, 1980 was simulated by the HSPF model. The HSPF model parameters were adjusted to have the simulated daily mean flow match the observed mean flow at the USGS gage station 02397000 . Table 4 presents the total flow volume through the USGS 02397000 location from 1972 to 1980 by month as well as the differences between the observed and the simulated flow volume (all less than 10\%). Fig. 14 presents the comparison of simulated and observed flow duration, and Fig. 15 shows the simulated and observed hydrography.

\section{6 $\underline{\text { HSPF Watershed Model Upstream from Plant Hammond }}$}

The HSPF watershed runoff models developed from the previous sections are combined to form the HSPF watershed runoff model for the entire basin upstream from Plant Hammond (Fig. 16) which is used to study the effect of future climate change on the available cooling water.

\subsection{RESULTS}

In this study, the watershed runoff model parameters were developed from Section 2. The runoff flows (hydrography) for the period 2040-2049 were calculated using downscaled meteorological data (Werth, 2011). The downscaling was performed using three GCMs i.e., the Goddard Institute of Space Studies (GISS) Model E, the Meteorological Research Institute (MRI) of Japan's model, and the Canadian Climate Center (CCC) model to provide hourly precipitation and temperature data for NWS Dalton, GA, Jasper, GA and Rome, GA. In addition, the runoff flows were calculated for the period 2040-2049 using the unscaled data. The unscaled data are the precipitation and temperature data interpolated from the original GCM data without downscaling to the regional/local conditions.

Fig. 17 shows the annual cycle of flow at Plant Hammond, both observed and modeled (19781979), for each month calculated over a two-year average. The broken red curve in Fig. 17 presents the observed flow which was influenced by the operation of dams. The solid red curve in Fig. 17 represents the simulated flow that would have occurred if there were no dams. One of the functions of the dam operation is to regulate the stream flow. This function can be found by comparing these two curves. The presence of the dam greatly reduces the flow in the spring (as water is stored in wet seasons), and leads to an increase in flow in the late fall (as the stored flow is now released in dry seasons). The BASINs simulation of the later period (using observed meteorology as input) reproduces the observed flow very closely, giving us more confidence in the simulations with future flow.

Fig. 18 shows the annual cycle of flow at Plant Hammond for both historical (1972-1979) and downscaled GCM (2042-2049) climate conditions, for each month calculated over a multi-year average. Fig. 18 illustrates that the differences of the multi-year averaged monthly flow between the historical and downscaled GCM climate conditions are small. Fig. 19 shows a similar comparison between the historical and unscaled GCM climate conditions. Fig. 19 illustrates that the unscaled GCM climate conditions produce flow significantly lower than the flow produced by 
the historical climate conditions. By comparing the plots in Fig. 18 and 19, it makes clear that using the unscaled GCM data would lead one to believe that winter flows will fall below the current levels, often by large percentages, while the use of downscaled data predicts flows closer to the more recent levels.

Fig. 18 and 19 show the differences of the mean monthly flow. Thus, the differences for the extreme flow (low or high flows) events were smeared by averaging processes in Fig. 18 and 19. Figs. 20 through 22 provide a comparison of simulated daily mean flow data (2042-2049) calculated for the scaled-vs-unscaled data for GISS, CCC, and MRI, respectively. For the GISS model, the effect of using the downscaled data is generally to increase the predicted flows, and the effect is more pronounced for the CCC and MRI models.

Fig. 23 presents the simulated daily mean flow frequency distributions over a period of eight years. The simulated results based on historical meteorological conditions (1972 to 1979) are represented by the black curve. The colored curves represent the simulated results based on future meteorological conditions determined from downscaling each of the GCMs. Fig. 23 shows that future flows are lower than the historical flows due to predicted climate change, except the downscaled MRI model which predicts greater flow at higher flow events. This implies that the downscaled MRI model predicts more chance of more extreme (high or low) flow events in the future weather condition relative to the current weather condition. If using the GCM model directly without scaling to regional conditions, the effect of the modeled climate change on flow reduction becomes more noticeable, as shown in Fig. 24.

The seven-day ten-year low flow (7Q10 flow) is the lowest average flow for seven consecutive days that has an average recurrence interval of ten years. Normally, calculation of 7Q10 flow requires greater than ten years of flow data. For the current study, watershed runoff flow was simulated for ten years. The first two years of simulated runoff flow were discarded as described in Section 2.1. In addition, the climatic year is from April 1 to March 31. Therefore, there are only seven years of flow data available for analysis. Nevertheless, these seven years of flow data were used to estimate 7Q10 flow for each of the future climate models as well as a historical weather condition. These calculated 7Q10 flow rates could give an estimate of the effect of future climate change on low flow. The circles in Fig. 25 represent the seven-day low flow frequency based on the simulated runoff flow from 1972 to 1979 . The solid line is a curve fit to the data points. The 7Q10 flow (recurrence of 10 years) extrapolated from Fig. 25 is $28.24 \mathrm{~m}^{3} / \mathrm{s}$. Using the same method for the future climate conditions (downscaled and unscaled GCMs), Fig. 26 shows the seven-day low-flow frequency curves for the downscaled and unscaled GCMs, as well as the historical condition. The seven-day low-flows are lower than the historical data except for the unscaled GISS data. For example, assume that a facility operated at a stream flow limit of $28.24 \mathrm{~m} 3 / \mathrm{s}$. Fig. 26 indicates that there is a chance of not meeting this flow limit 1 in 10 years based on historical climate conditions. Based on future downscaled MRI GCM data, the chance of not meeting the flow limit is increased to 1 in 5 years. Based on unscaled MRI GCM data, the facility might not meet the flow limit 1 in 2.4 years. This analysis demonstrates the value of the downscaled GCM to the regional/local conditions. Table 5 presents the estimated 7Q10 flows for the historical and future (downscaled and unscaled) climate conditions. The 7Q10 flows based on unscaled GCM data are significantly lower than the historical 7Q10 flow except for the GISS GCM data.

\subsection{CONCLUSIONS}

A statistical downscaling method was used to predict hourly temperature and precipitation data at specific NWS observation sites for the period of 2040 to 2049. The resulting future regional 
weather conditions were used to predict the flow within the Coosa River basin upstream from Plant Hammond in northwest Georgia. The watershed characteristics obtained from Section 2 were used in these simulations, which assumes no changes in land use/land cover. Also, watershed runoff simulations were conducted with unscaled data interpolated from the original GCM simulations for an identical period. The study shows that: 1) the differences of the multiyear averaged monthly flow between the historical and downscaled GCM climate conditions are small because the extreme flows (high/low flow) were smeared by the averaging process, 2 ) in general, the simulated daily mean flow using the unscaled GCM data is lower than the daily mean flow simulated by using the downscaled GCM data. However, for some low flow events, the unscaled GISS data produce daily mean flow higher than the flow produced by the downscaled GISS data, and 3) compared to the flow predicted by the historical climate condition, future flows are lower than the historical flows due to predicted climate change, except for two cases. For some high flow events, the downscaled MRI GCM model predicts greater flow than the historical condition. For some low flow events, the unscaled GISS GCM model predicts flow higher than the flow predicted by the historical condition.

The 7Q10 flow predicted by the future climate conditions is lower than the 7Q10 flow predicted by the historical climate condition, except the 7Q10 flow predicted by the unscaled GISS GCM data.

The contrast between the two methods is clear - the use of downscaled data led to significantly greater flows in the basin than the simulation does without applying downscaling to the original GCM data, which called for strong decreases in the basin flow (except GISS). A water management plan based on the latter would call for much more stringent restrictions than one based on the former. This study demonstrates the practical usefulness of downscaling in decisions on future water resource management.

\subsection{REFERENCES}

Bicknell, BR; Imhoff, JC; Kittle,JL, Jr; et al. (2005) Hydrological Simulation Program FORTRAN (HSPF). User's manual for release 12.2 U.S. EPA National Exposure Research Laboratory, Athens, GA, in cooperation with U.S. Geological Survey, WRD, Reston, VA.

BASIN 4 Training Lecture 5 (August, 2010):

http://water.epa.gov/scitech/datait/models/basins/training.cfm

GeorgiaInfo: http://georgiainfo.galileo.usg.edu/conasaugariver.htm

Joyner, Chris: Deal's water plans advance despite concerns, Atlanta Journal-Constitution, April 12,2011

U.S. EPA (Environmental Protection Agency). (2007) BASINS 4.0. U.S. Environmental Protection Agency, Washington, DC. EPA/823/C-07/001

Werth, D. W., and Kuo-Fu Chen (2011) The Application of a Statistical Downscaling Process to Derive $21^{\text {st }}$ Century River Flow Predictions Using Global Climate Model Data (to be published) 
Table 1 Comparison of Conasauga River Watershed Outlet Flow Volume at USGS02387000

\begin{tabular}{|c|l|c|c|}
\hline \multirow{2}{*}{ Month } & \multicolumn{2}{|c|}{ Flow Volume $\left(\mathrm{m}^{3}\right)$} & Percent \\
\cline { 2 - 3 } & Observed & Simulated & Difference \\
\hline Jan & $7.8041 \mathrm{E}+08$ & $8.2447 \mathrm{E}+08$ & 5.65 \\
\hline Feb & $9.1762 \mathrm{E}+08$ & $9.3120 \mathrm{E}+08$ & 1.48 \\
\hline Mar & $9.5154 \mathrm{E}+08$ & $9.1763 \mathrm{E}+08$ & -3.56 \\
\hline Apr & $3.6180 \mathrm{E}+08$ & $3.4827 \mathrm{E}+08$ & -3.74 \\
\hline May & $2.3394 \mathrm{E}+08$ & $2.5725 \mathrm{E}+08$ & 9.97 \\
\hline Jun & $2.9732 \mathrm{E}+08$ & $2.6804 \mathrm{E}+08$ & -9.85 \\
\hline Jul & $1.7811 \mathrm{E}+08$ & $1.7021 \mathrm{E}+08$ & -4.44 \\
\hline Aug & $8.0340 \mathrm{E}+07$ & $8.8254 \mathrm{E}+07$ & 9.85 \\
\hline Sep & $1.8020 \mathrm{E}+08$ & $1.6303 \mathrm{E}+08$ & -9.52 \\
\hline Oct & $3.3318 \mathrm{E}+08$ & $3.1946 \mathrm{E}+08$ & -4.12 \\
\hline Nov & $3.8957 \mathrm{E}+08$ & $4.0041 \mathrm{E}+08$ & 2.78 \\
\hline Dec & $4.8068 \mathrm{E}+08$ & $5.2134 \mathrm{E}+08$ & 8.46 \\
\hline
\end{tabular}


Table 2 Comparison of Coosawattee River Watershed Outlet Flow Volume at USGS02383500

\begin{tabular}{|c|c|c|c|}
\hline \multirow{2}{*}{ Month } & \multicolumn{2}{|c|}{ Flow Volume $\left(\mathrm{m}^{3}\right)$} & \multirow{2}{*}{$\begin{array}{c}\text { Percent } \\
\text { Difference }\end{array}$} \\
\hline & Observed & Simulated & \\
\hline Jan & $6.5970 \mathrm{E}+08$ & $6.2517 \mathrm{E}+08$ & -5.23 \\
\hline Feb & $9.2520 \mathrm{E}+08$ & $9.1517 \mathrm{E}+08$ & -1.08 \\
\hline Mar & $8.1559 \mathrm{E}+08$ & $7.8350 \mathrm{E}+08$ & -3.93 \\
\hline Apr & $9.8847 \mathrm{E}+08$ & $9.3362 \mathrm{E}+08$ & -5.55 \\
\hline May & $5.7203 \mathrm{E}+08$ & $5.9155 \mathrm{E}+08$ & 3.41 \\
\hline Jun & $3.8885 \mathrm{E}+08$ & $3.6056 \mathrm{E}+08$ & -7.28 \\
\hline Jul & $2.9250 \mathrm{E}+08$ & $3.1487 \mathrm{E}+08$ & 7.65 \\
\hline Aug & $2.1005 \mathrm{E}+08$ & $2.2296 \mathrm{E}+08$ & 6.15 \\
\hline Sep & $1.9762 \mathrm{E}+08$ & $2.1286 \mathrm{E}+08$ & 7.71 \\
\hline Oct & $2.2630 \mathrm{E}+08$ & $2.4690 \mathrm{E}+08$ & 9.11 \\
\hline Nov & $3.4614 \mathrm{E}+08$ & $3.4833 \mathrm{E}+08$ & 0.63 \\
\hline Dec & $5.0606 \mathrm{E}+08$ & $5.0357 \mathrm{E}+08$ & -0.49 \\
\hline
\end{tabular}


Table 3 Comparison of Etowah River Watershed Outlet Flow Volume at USGS02396000

\begin{tabular}{|c|c|c|c|}
\hline \multirow{2}{*}{ Month } & \multicolumn{2}{|c|}{ Flow Volume $\left(\mathrm{m}^{3}\right)$} & \multirow{2}{*}{$\begin{array}{c}\text { Percent } \\
\text { Difference }\end{array}$} \\
\cline { 2 - 3 } Jan & $8.6316 \mathrm{E}+08$ & $8.6264 \mathrm{E}+08$ & -0.06 \\
\hline Feb & $1.3526 \mathrm{E}+09$ & $1.4768 \mathrm{E}+09$ & 9.19 \\
\hline Mar & $1.9557 \mathrm{E}+09$ & $2.0207 \mathrm{E}+09$ & 3.32 \\
\hline Apr & $1.3540 \mathrm{E}+09$ & $1.4211 \mathrm{E}+09$ & 4.95 \\
\hline May & $9.1971 \mathrm{E}+08$ & $8.5207 \mathrm{E}+08$ & -7.35 \\
\hline Jun & $5.9958 \mathrm{E}+08$ & $6.2609 \mathrm{E}+08$ & 4.42 \\
\hline Jul & $7.5945 \mathrm{E}+08$ & $7.0497 \mathrm{E}+08$ & -7.17 \\
\hline Aug & $5.5129 \mathrm{E}+08$ & $5.0803 \mathrm{E}+08$ & -7.85 \\
\hline Sep & $4.5625 \mathrm{E}+08$ & $5.0158 \mathrm{E}+08$ & 9.93 \\
\hline Oct & $3.8033 \mathrm{E}+08$ & $4.1051 \mathrm{E}+08$ & 7.94 \\
\hline Nov & $4.1875 \mathrm{E}+08$ & $3.7737 \mathrm{E}+08$ & -9.88 \\
\hline Dec & $9.4310 \mathrm{E}+08$ & $8.7239 \mathrm{E}+08$ & -7.50 \\
\hline
\end{tabular}


Table 4 Comparison of Upper Coosa and Oostanaula Watershed Outlet Flow Volume at USGS02397000

\begin{tabular}{|c|l|l|c|}
\hline \multirow{2}{*}{ Month } & \multicolumn{2}{|c|}{ Flow Volume $\left(\mathrm{m}^{3}\right)$} & Percent \\
\cline { 2 - 3 } & Observed & Simulated & Difference \\
\hline Jan & $4.2888 \mathrm{E}+09$ & $4.5567 \mathrm{E}+09$ & 6.25 \\
\hline Feb & $2.5987 \mathrm{E}+09$ & $2.7893 \mathrm{E}+09$ & 7.33 \\
\hline Mar & $6.8141 \mathrm{E}+09$ & $6.9774 \mathrm{E}+09$ & 2.40 \\
\hline Apr & $6.5352 \mathrm{E}+09$ & $6.2914 \mathrm{E}+09$ & -3.73 \\
\hline May & $3.4972 \mathrm{E}+09$ & $3.5971 \mathrm{E}+09$ & 2.85 \\
\hline Jun & $1.9051 \mathrm{E}+09$ & $1.9887 \mathrm{E}+09$ & 4.39 \\
\hline Jul & $1.8961 \mathrm{E}+09$ & $2.0297 \mathrm{E}+09$ & 7.04 \\
\hline Aug & $1.2623 \mathrm{E}+09$ & $1.3398 \mathrm{E}+09$ & 6.14 \\
\hline Sep & $1.1775 \mathrm{E}+09$ & $1.2351 \mathrm{E}+09$ & 4.89 \\
\hline Oct & $1.3858 \mathrm{E}+09$ & $1.4883 \mathrm{E}+09$ & 7.39 \\
\hline Nov & $2.3712 \mathrm{E}+09$ & $2.4893 \mathrm{E}+09$ & 4.98 \\
\hline Dec & $2.0182 \mathrm{E}+09$ & $2.2082 \mathrm{E}+09$ & 9.41 \\
\hline
\end{tabular}


Table 5 Estimated 7Q10 Flow

\begin{tabular}{|c|c|c|}
\hline \multicolumn{3}{|c|}{ 7Q10 Flow $\left(\mathrm{m}^{3} / \mathbf{s}\right)$} \\
\hline Historical & \multicolumn{2}{|c|}{28.24} \\
\hline GCM & Downscaled & Un-scaled \\
\hline CCC & 21.42 & 14.24 \\
\hline GISS & 25.61 & 32.28 \\
\hline MRI & 24.97 & 21.53 \\
\hline
\end{tabular}


Figure 1

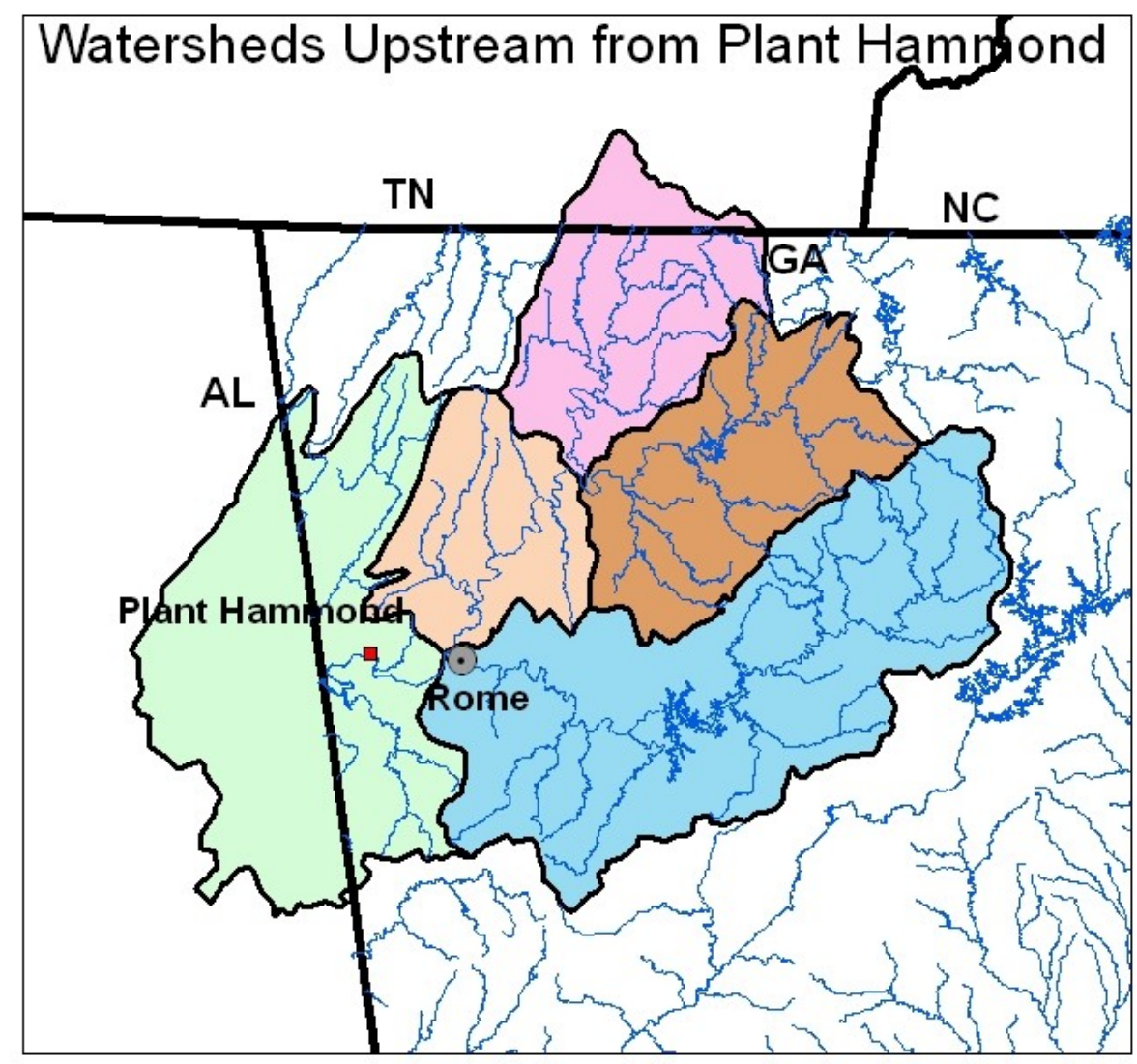

\section{Legend}

Watershed

$\square$ Upper Coosa. Alabama, Georgia.

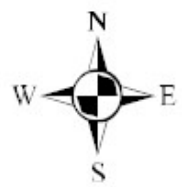

$\square$ Oostanaula. Georgia.

$\square$ Etowah. Georgia.

$\square$ Coosawattee. Georgia.

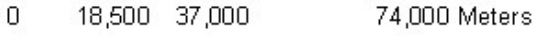

Conasauga. Georgia, Tennessee. 
Figure 2

\section{HYDROLOGY - HYDROLOGIC COMPONENTS}

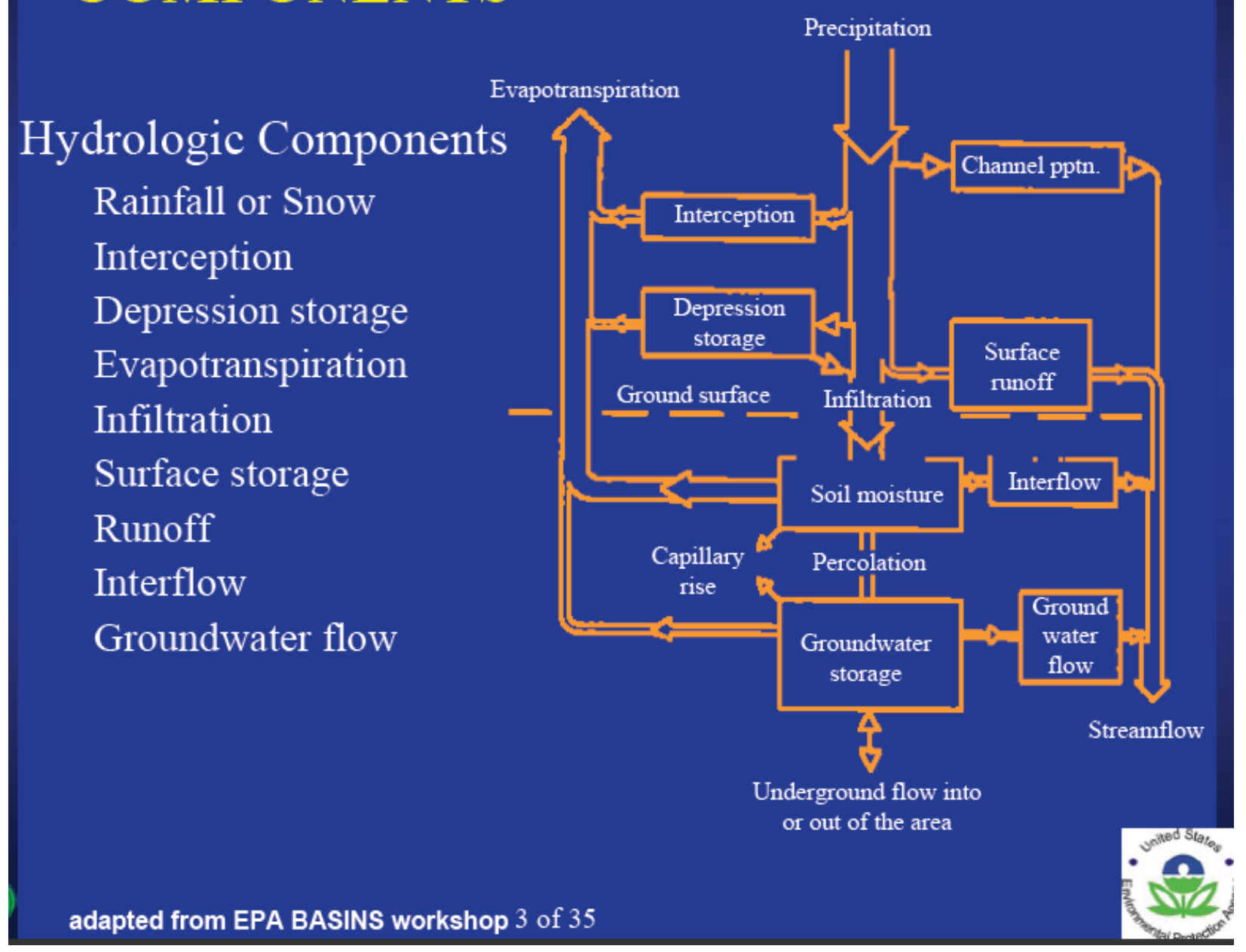

BASIN 4 Training Lecture 5:

http://water.epa.gov/scitech/datait/models/basins/training.cfm 
Figure 3

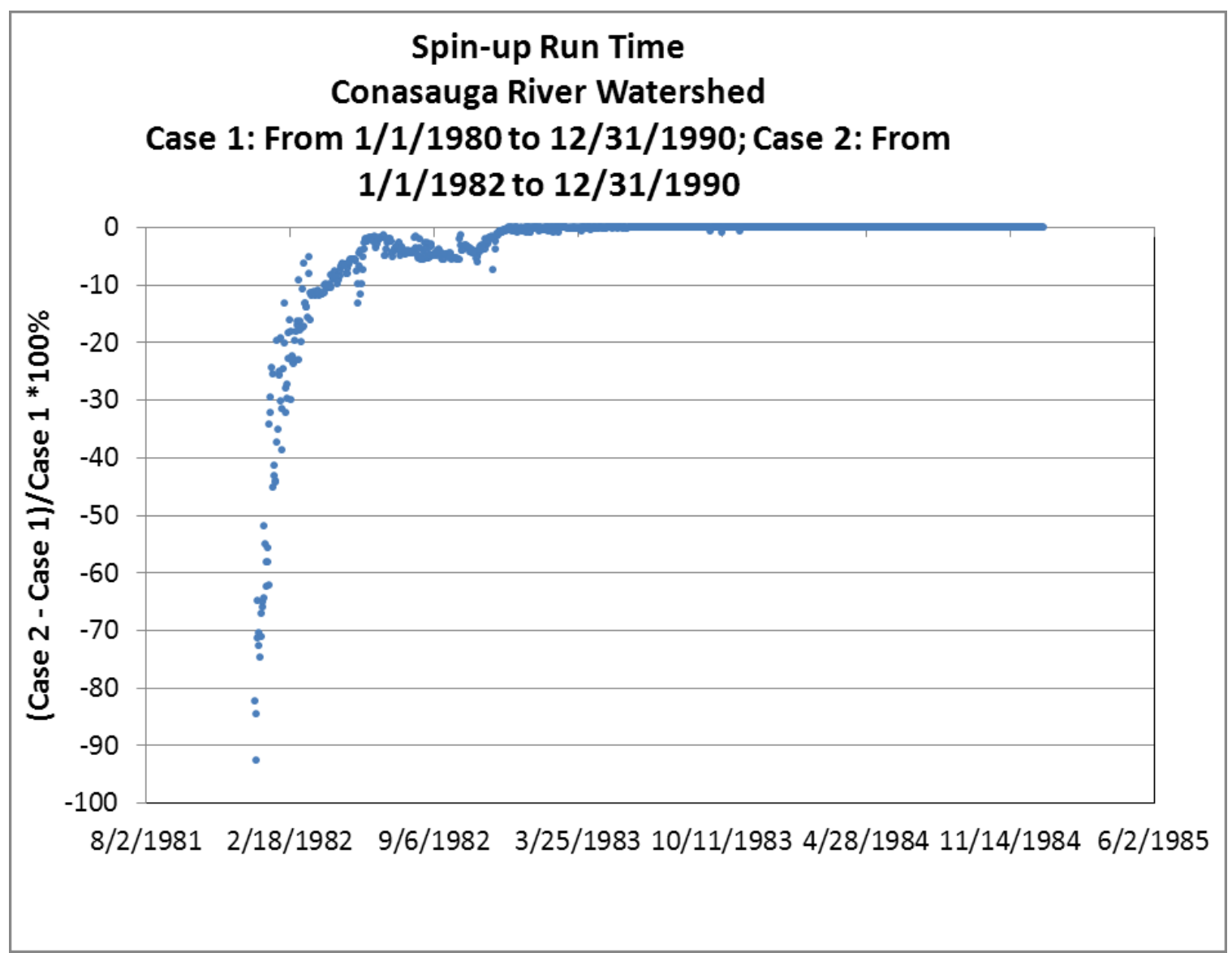


Figure 4

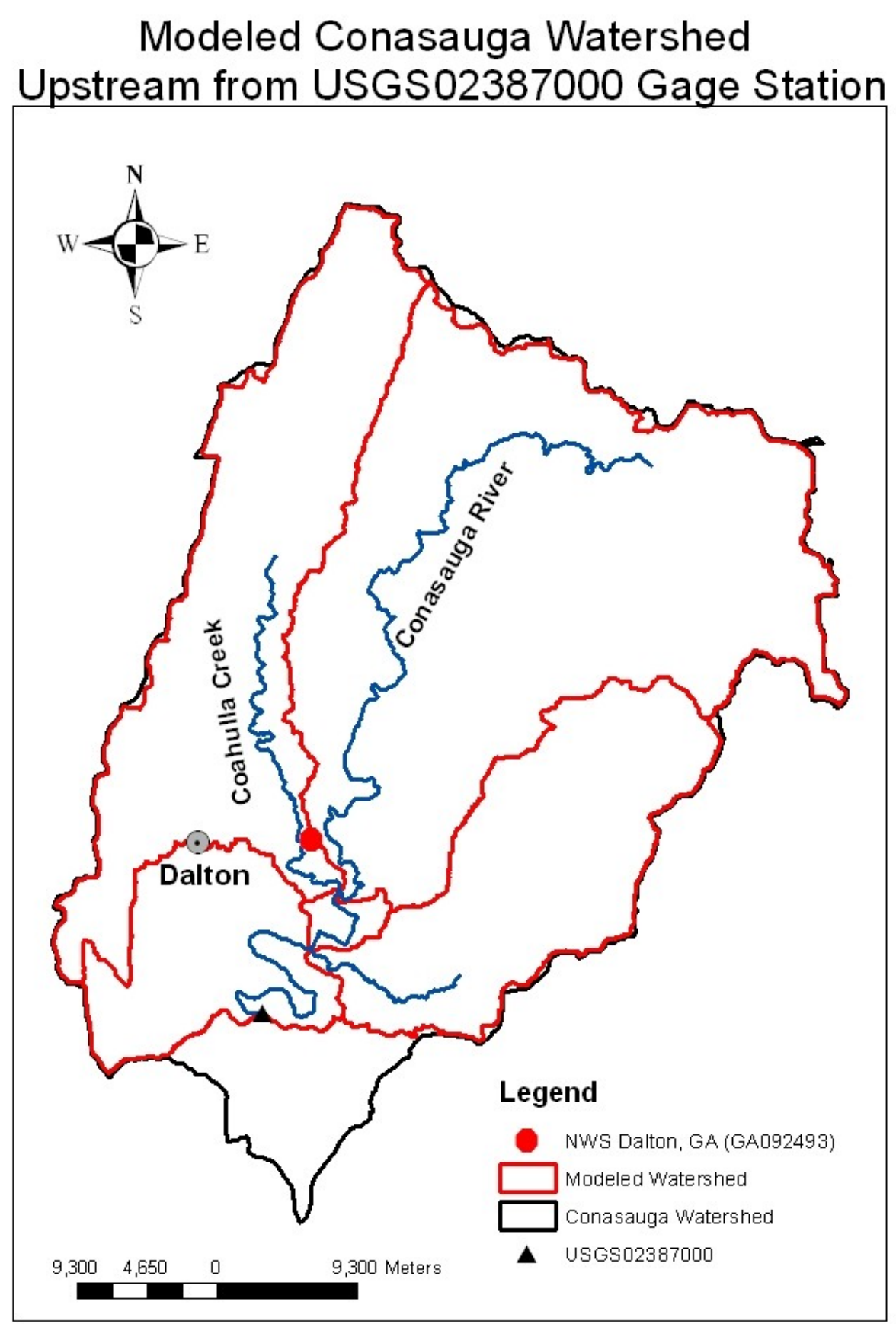


SRNL-STI-2011-00651

Revision 0

Figure 5 Simulated and Observed Conasauga Watershed Flow Duration

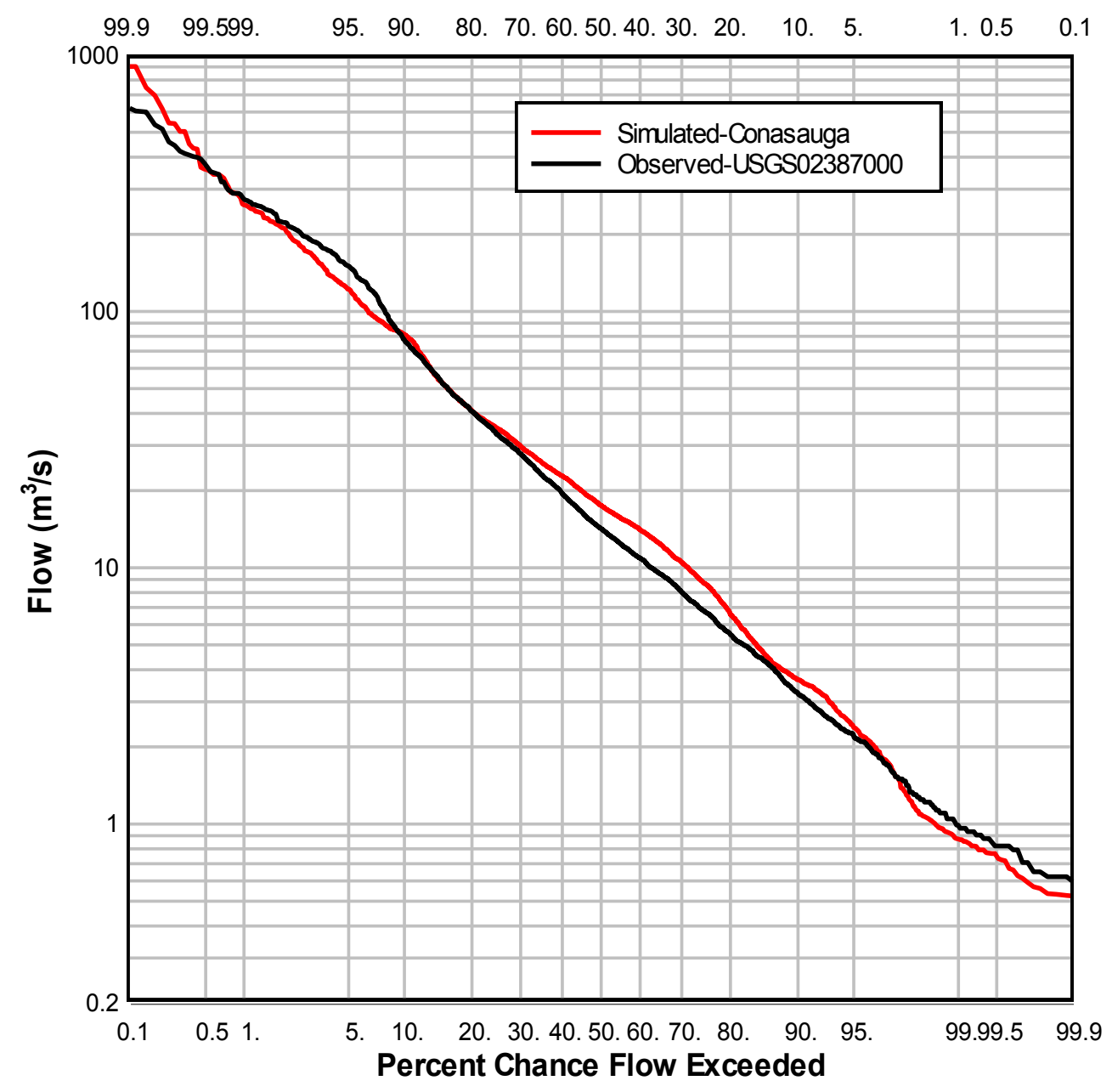


SRNL-STI-2011-00651

Revision 0

Figure 6 Simulated and Observed Conasauga River Watershed Daily Mean Flow at USGS02387000

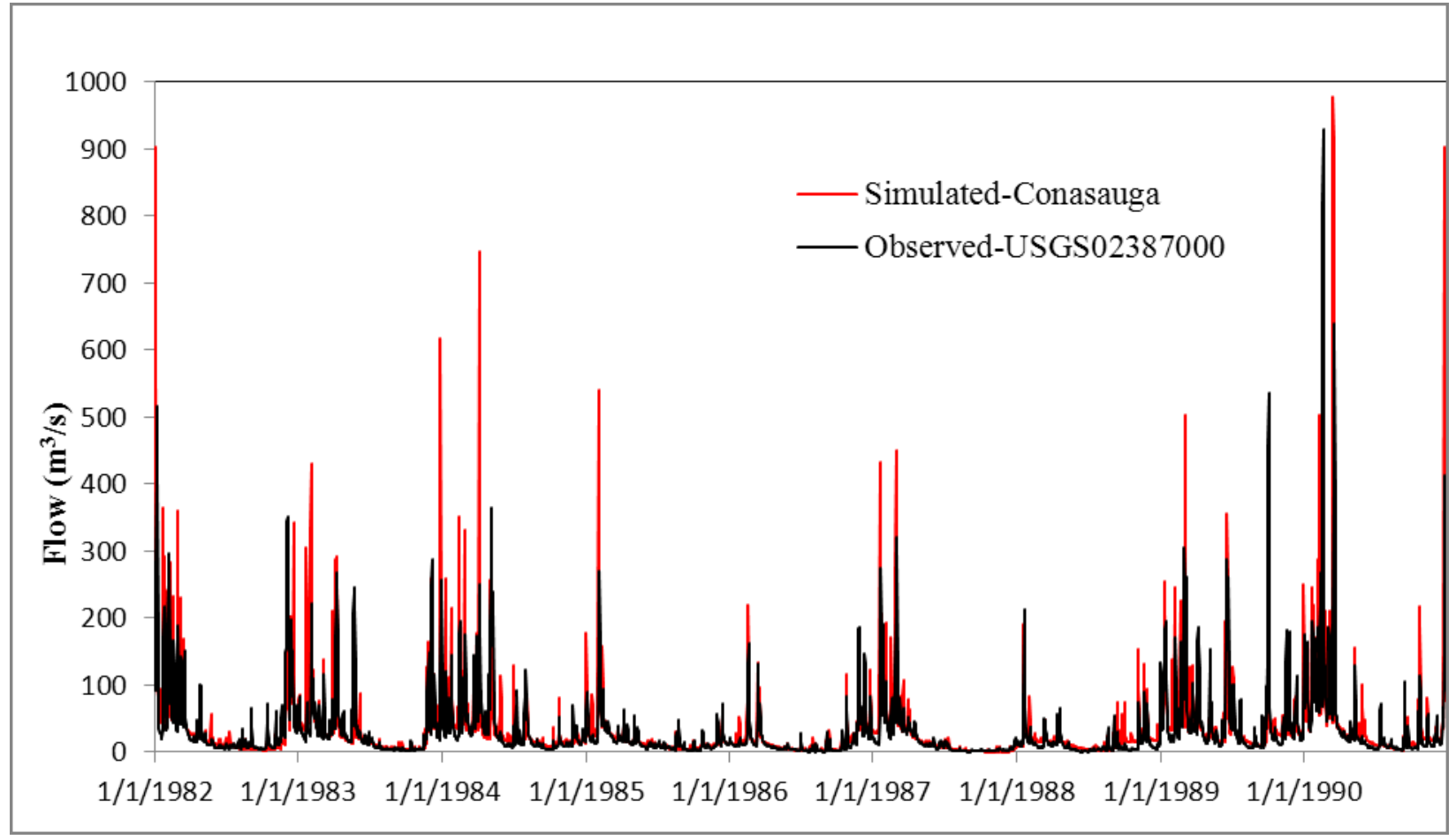


Figure 7
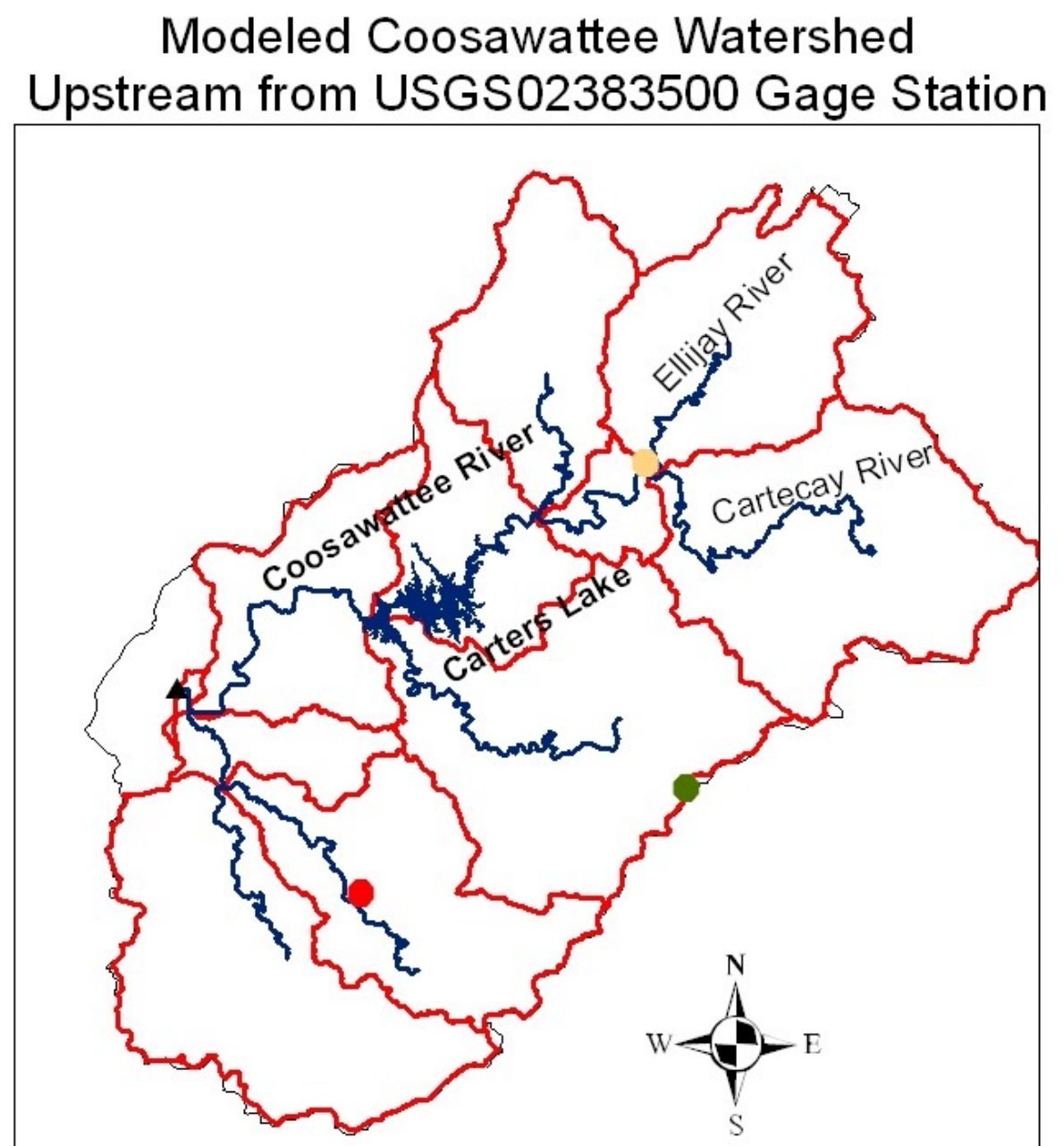

\section{Legend}

$\begin{array}{lllll}0 & 3,4506,900 & 13,800 & 20,700 & 27,600\end{array}$

NWS Ellijay, GA (GA093115)

- NWS Fairmount, GA (GA093295)

- NWS Jasper, GA (GA094648)

$\square$ Modeled Watershed

Coosawattee Watershed

A USGS02383500 
SRNL-STI-2011-00651

Revision 0

Figure 8 Simulated and Observed Coosawattee Watershed Flow Duration

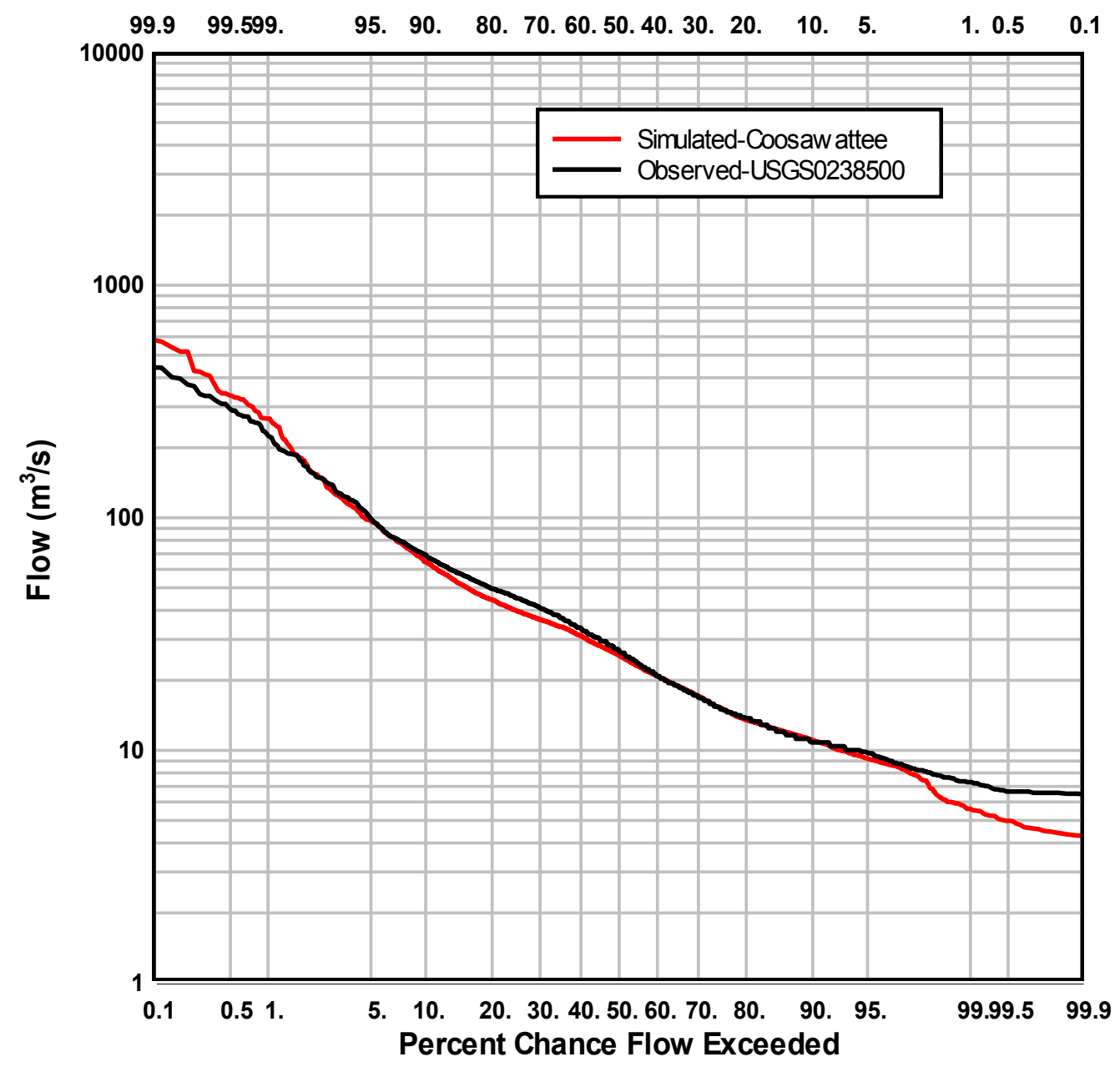


SRNL-STI-2011-00651

Revision 0

Figure 9 Simulated and Observed Coosawattee River Watershed Daily Mean Flow at USGS02383500

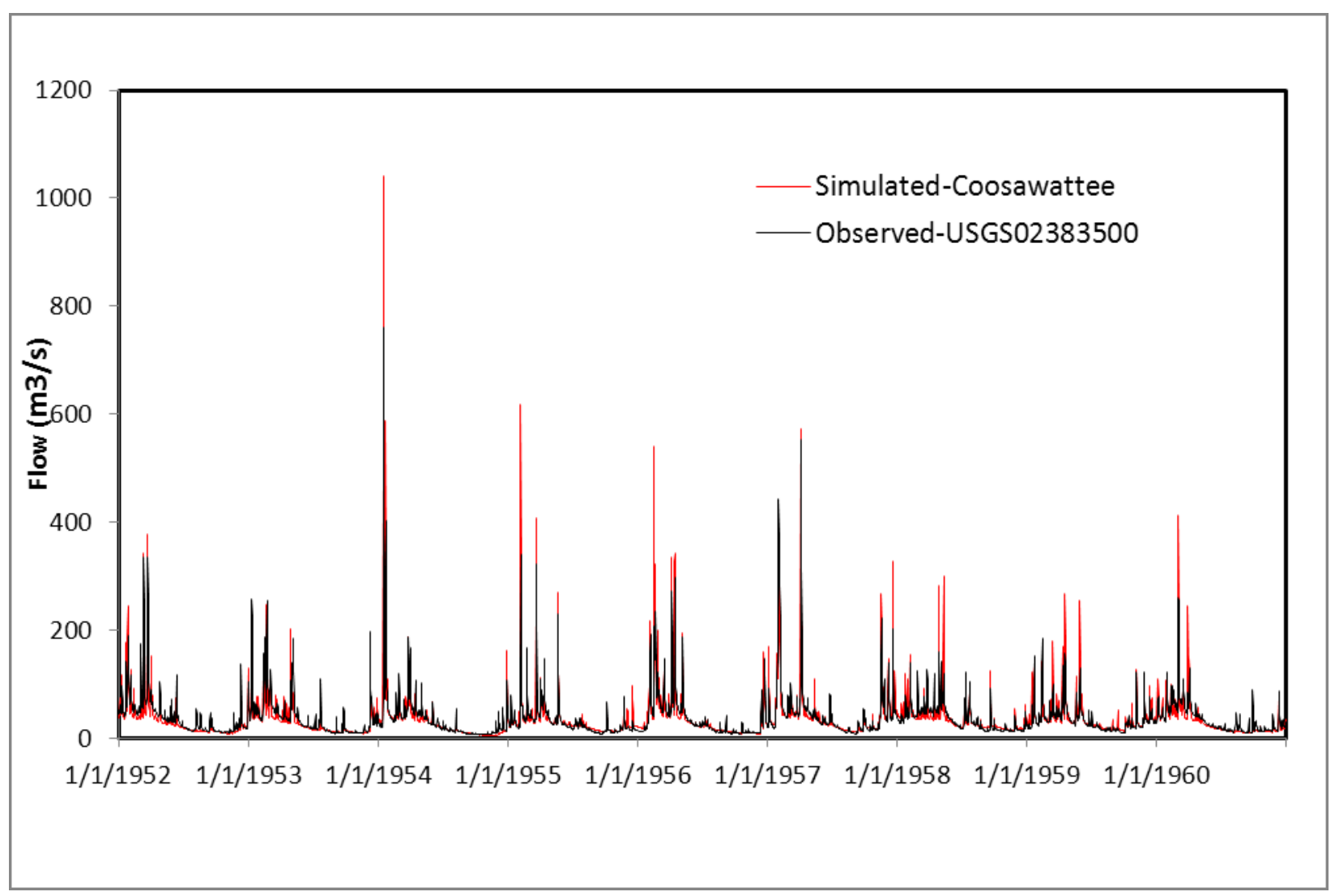


SRNL-STI-2011-00651

Revision 0

Figure 10

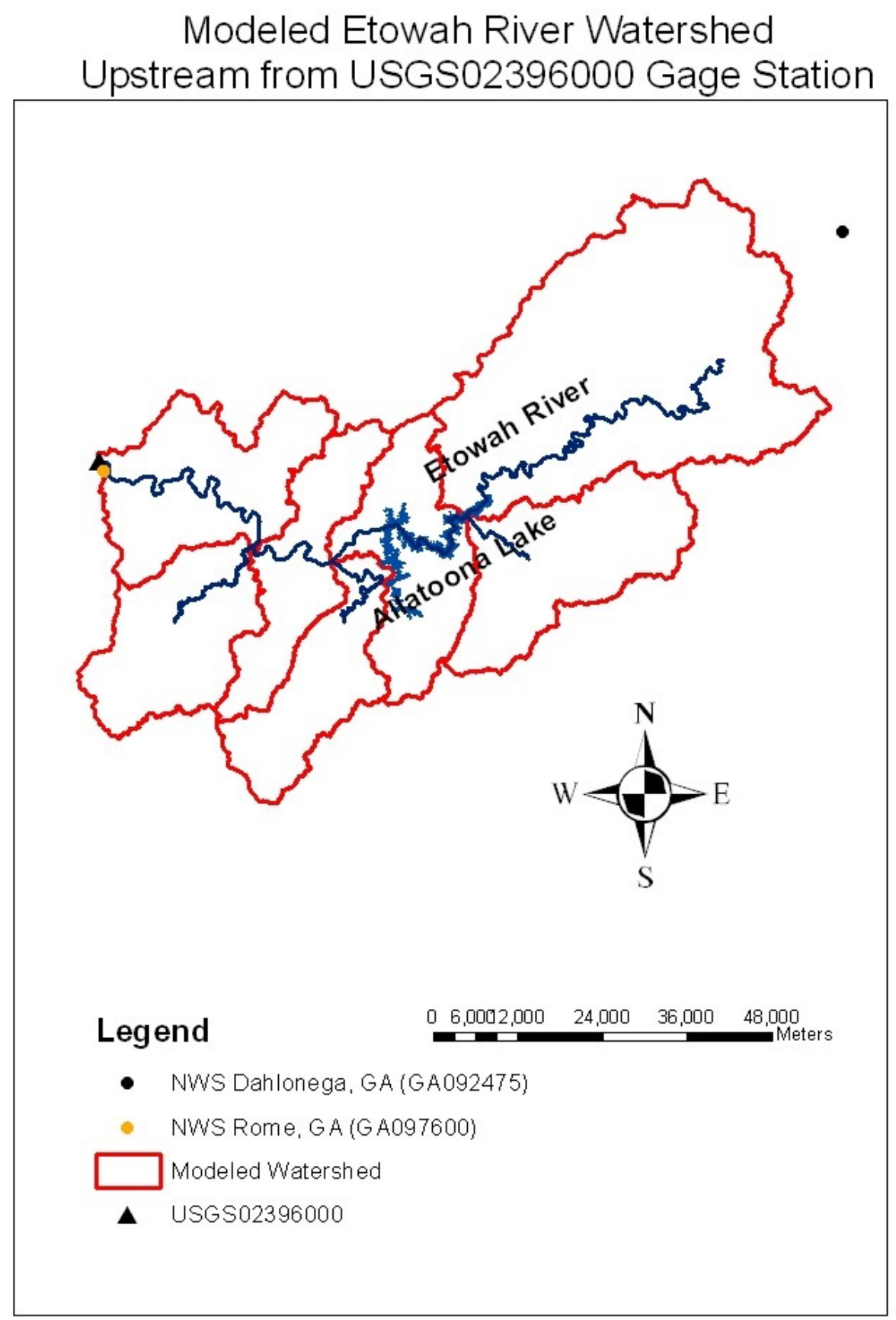


SRNL-STI-2011-00651

Revision 0

Figure 11 Simulated and Observed Etowah Watershed Flow Duration

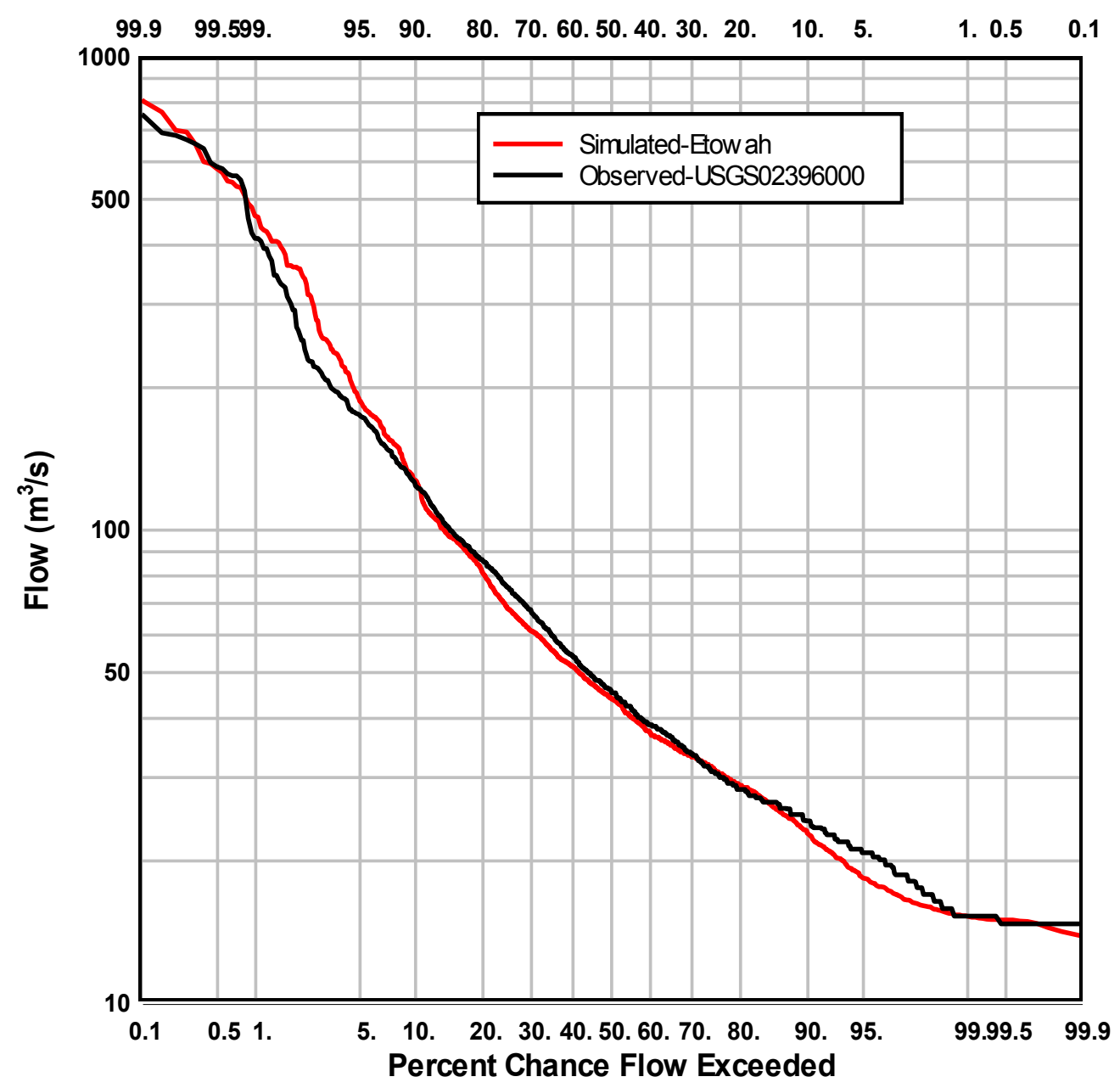


Figure 12 Simulated and Observed Etowah River Watershed Daily Mean Flow at USGS02396000

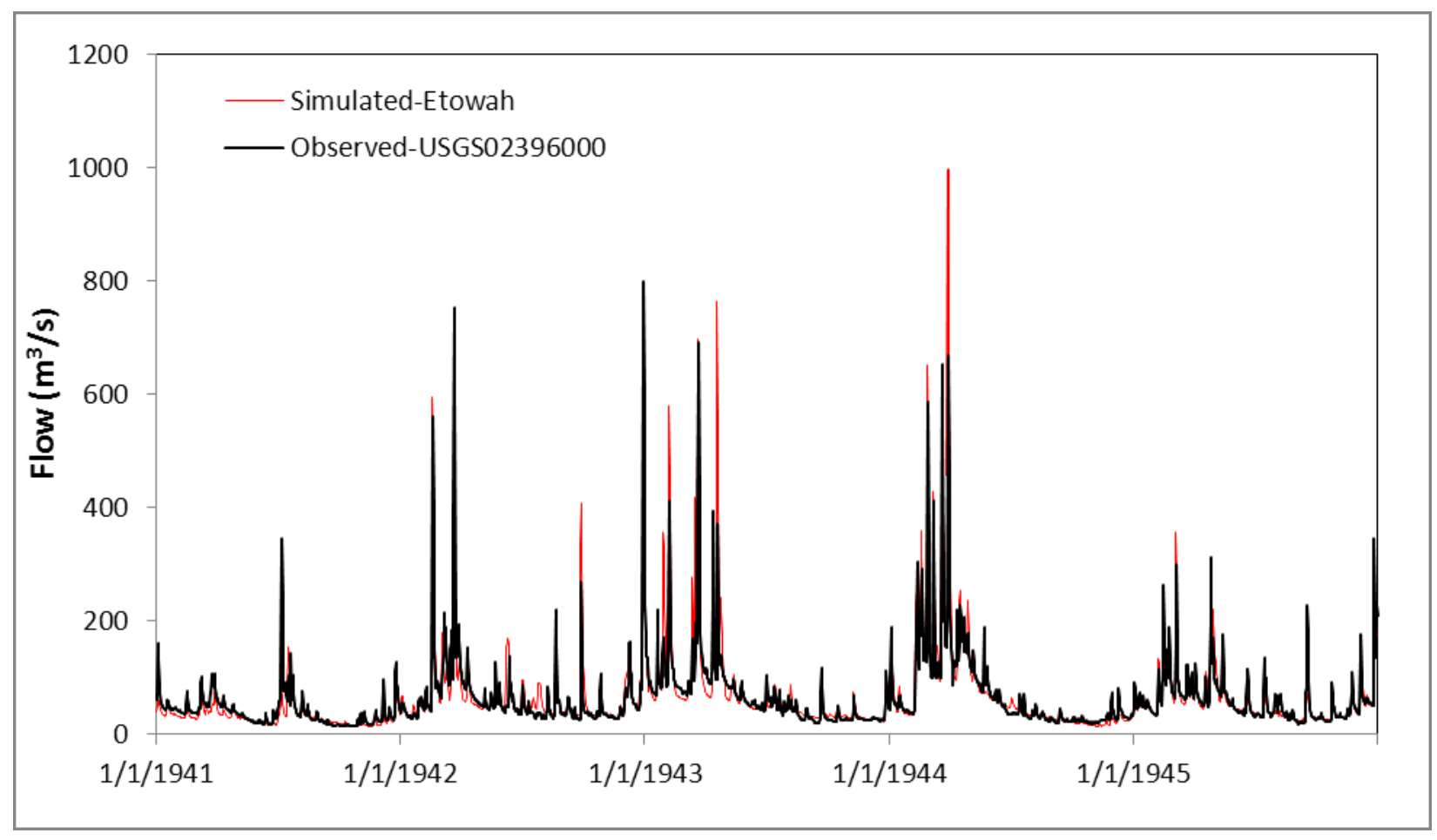


Figure 13

Modeled Upper Coosa \& Oostanaula Watersheds

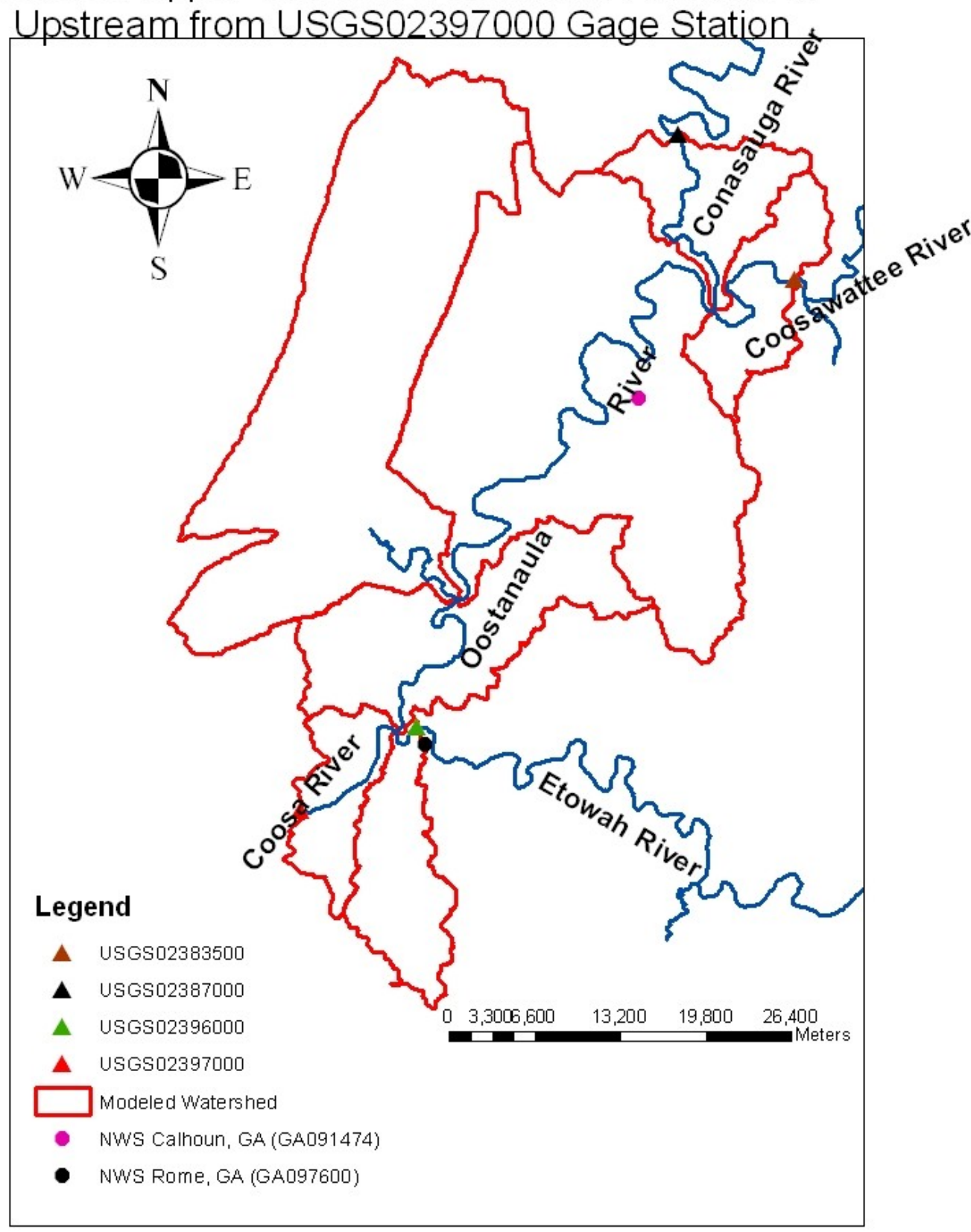


SRNL-STI-2011-00651

Revision 0

Figure 14 Simulated and Observed Upper Coosa and Oostanaula Watersheds Flow Duration

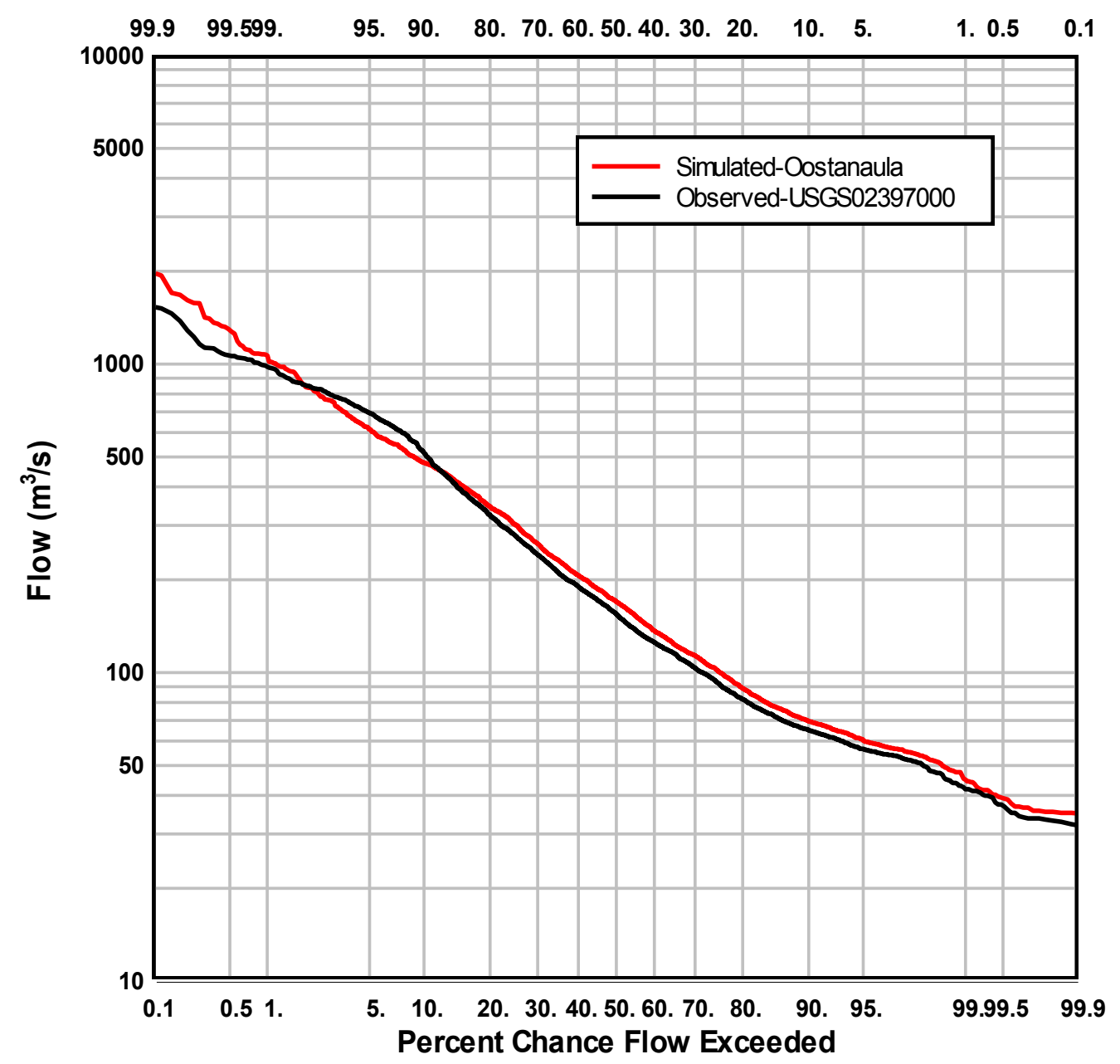


Figure 15 Simulated and Observed Upper Coosa and Oostanaula River Watersheds Daily Mean Flow at USGS02397000

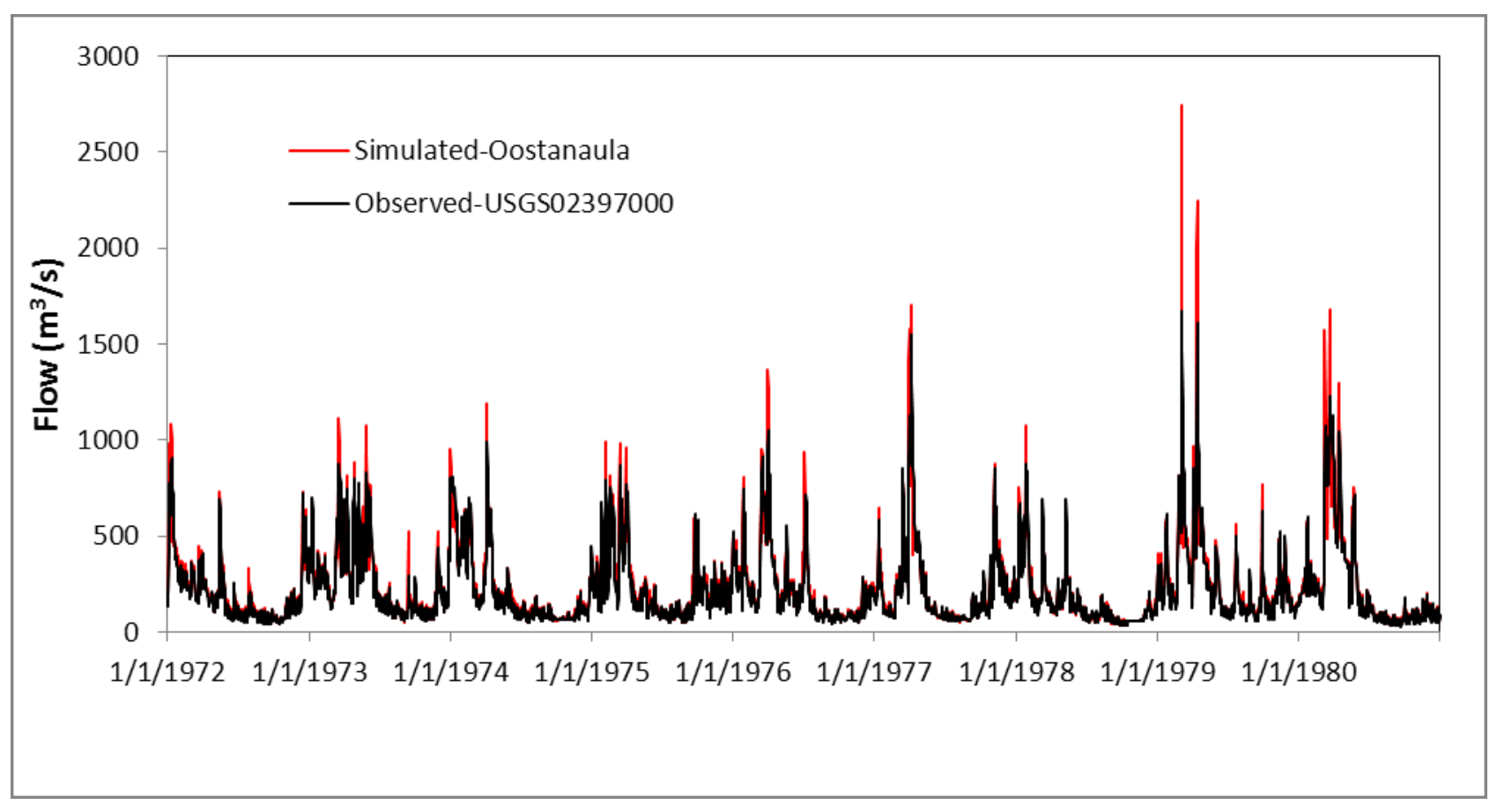


Figure 16

\section{Modeled Watershed Upstream from Plant Hammond}

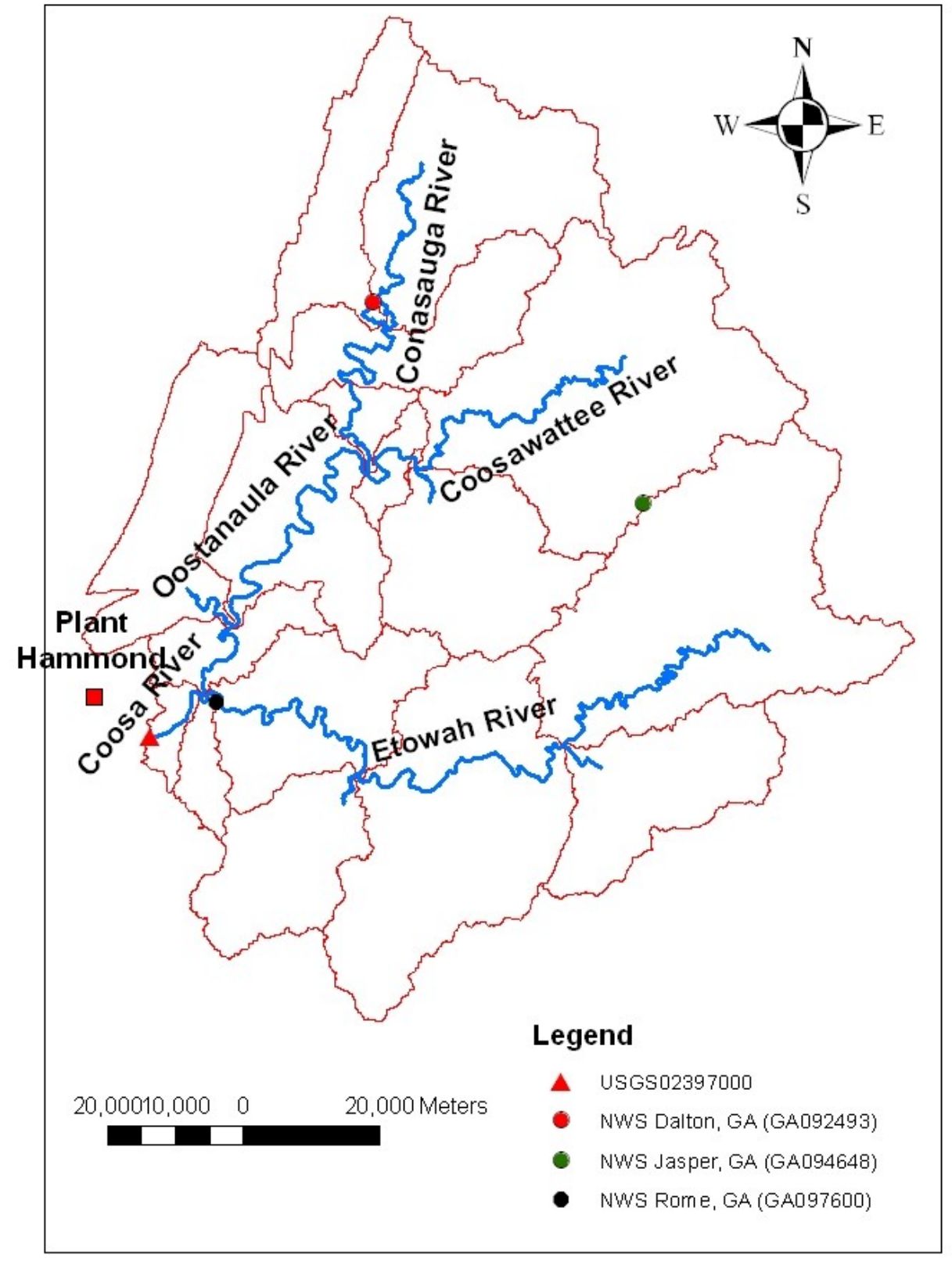


Figure 17

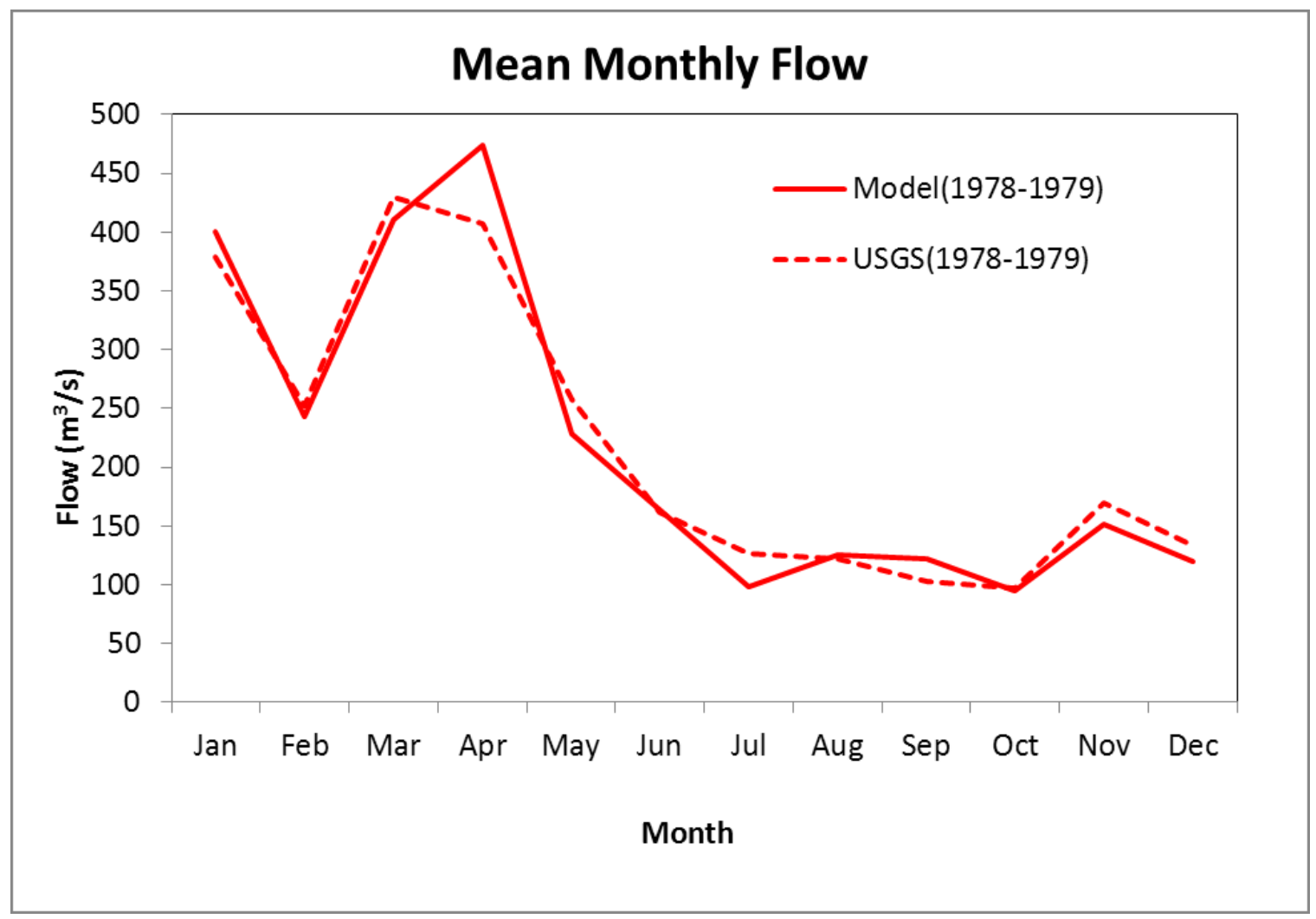


Figure 18

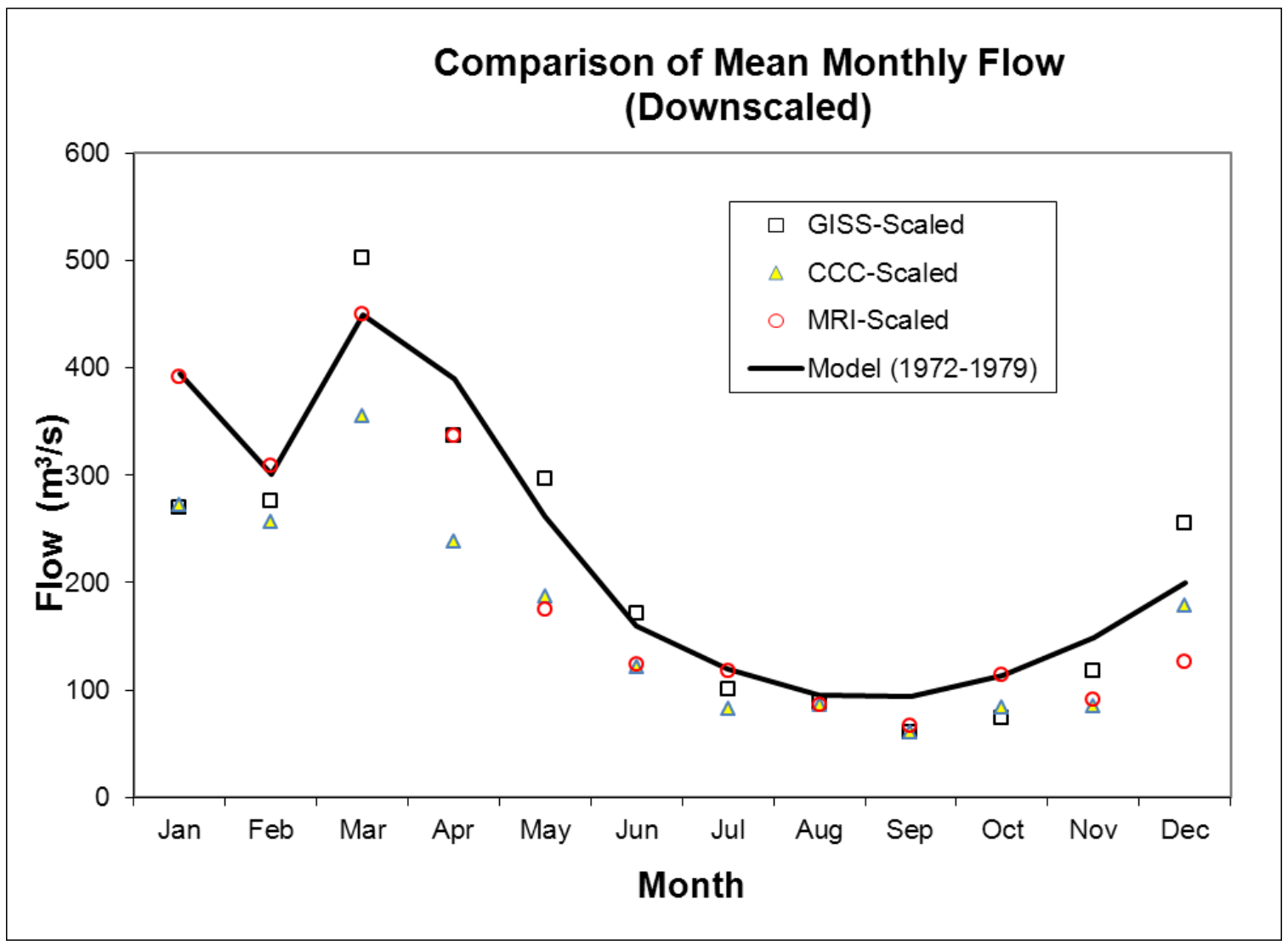


Figure 19

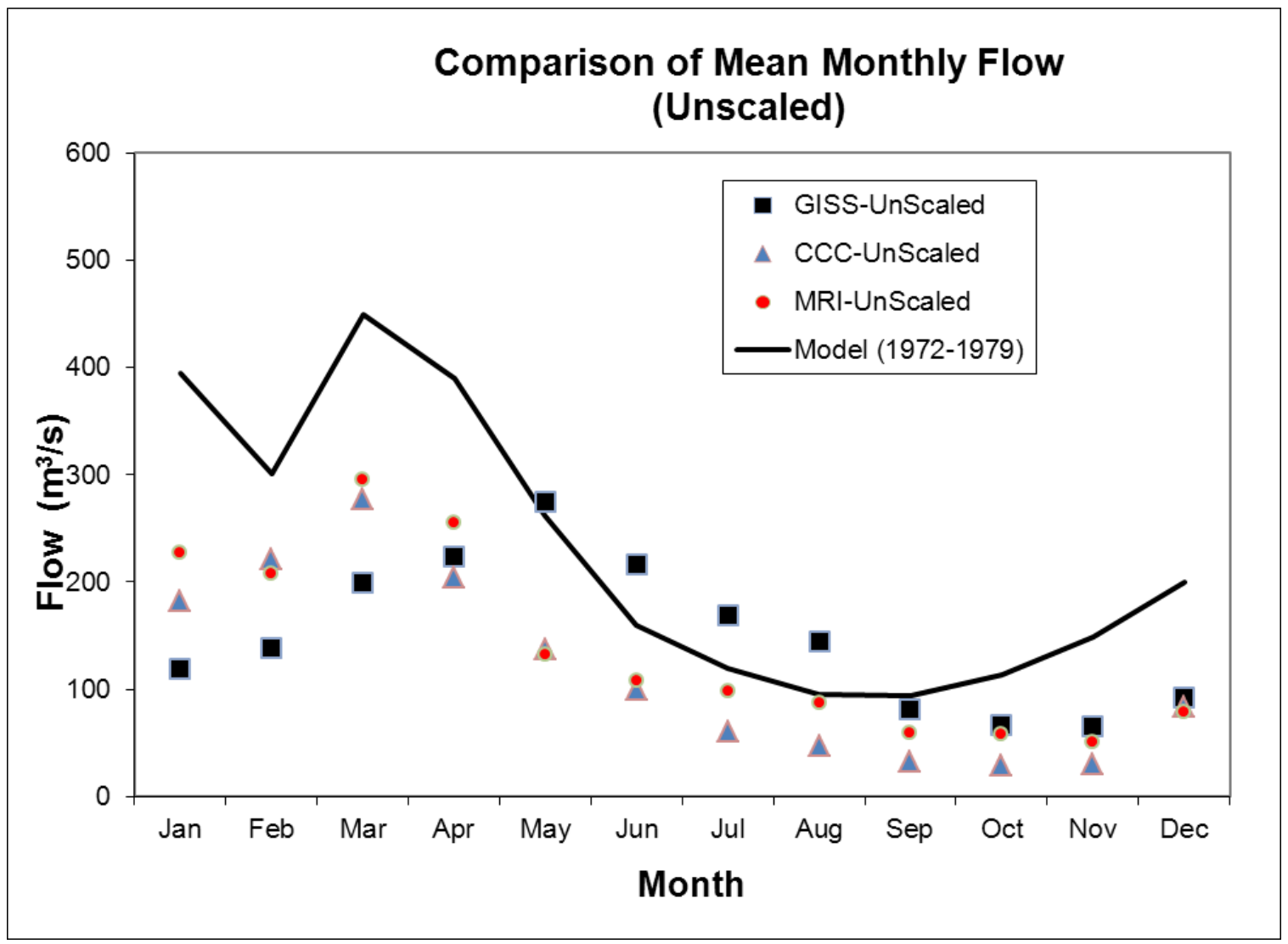


Figure 20

Calculated Daily Mean Flow from 2042 to 2049 at Plant Hammond GISS

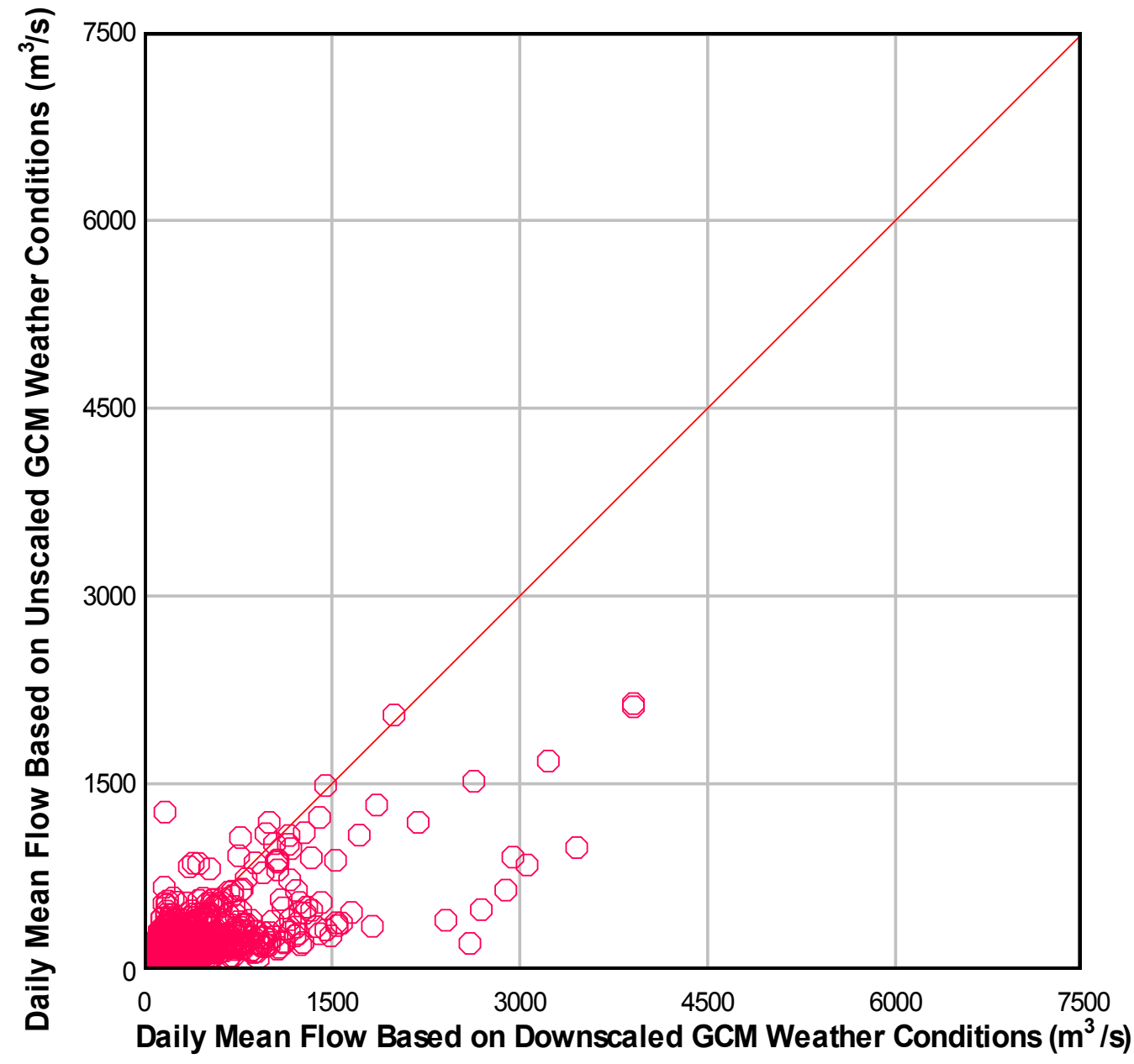


SRNL-STI-2011-00651

Revision 0

Figure 21

Calculated Daily Mean Flow from 2042 to 2049 at Plant Hammond CCC

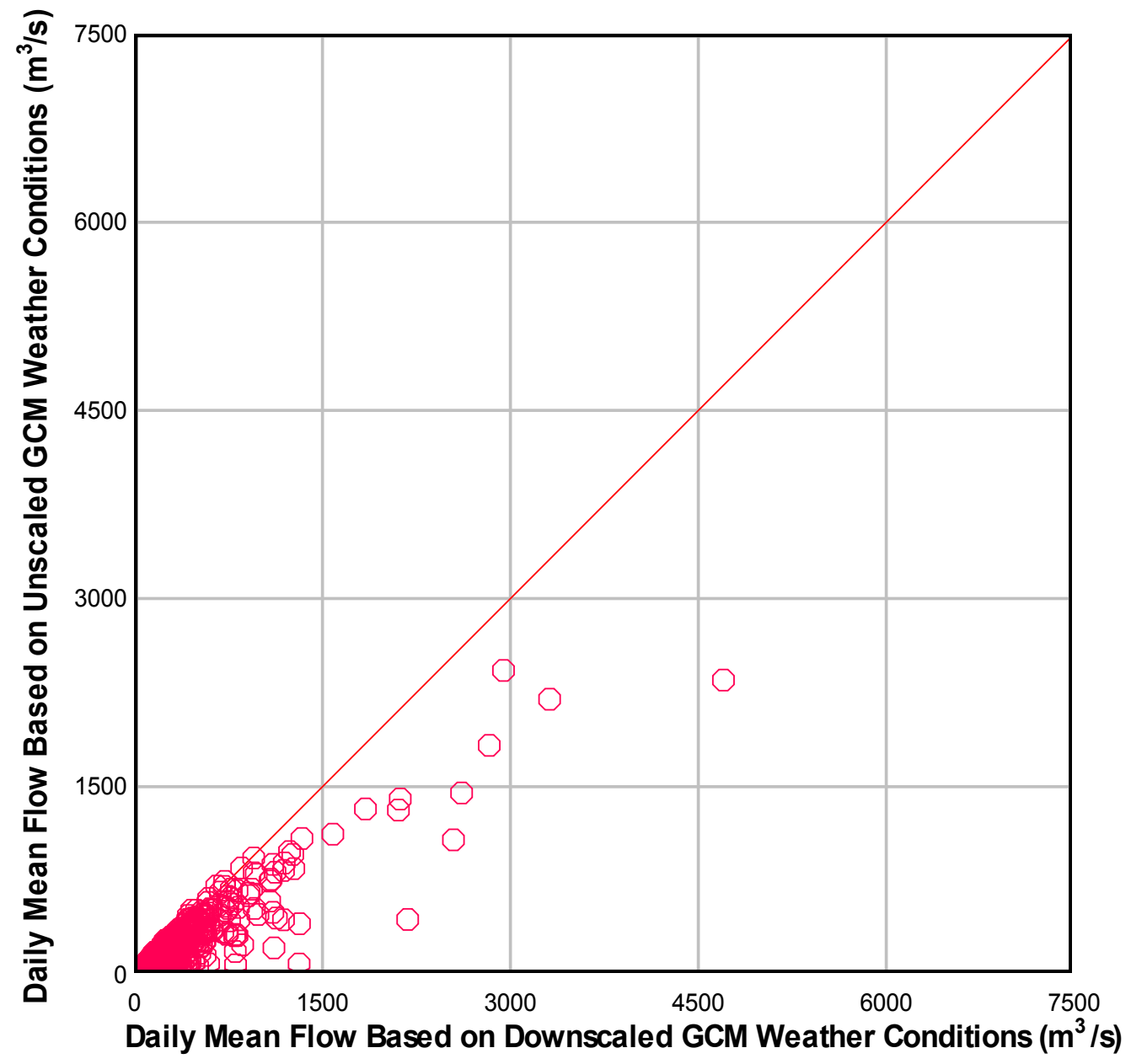


Figure 22

Calculated Daily Mean Flow from 2042 to 2049 at Plant Hammond MRI

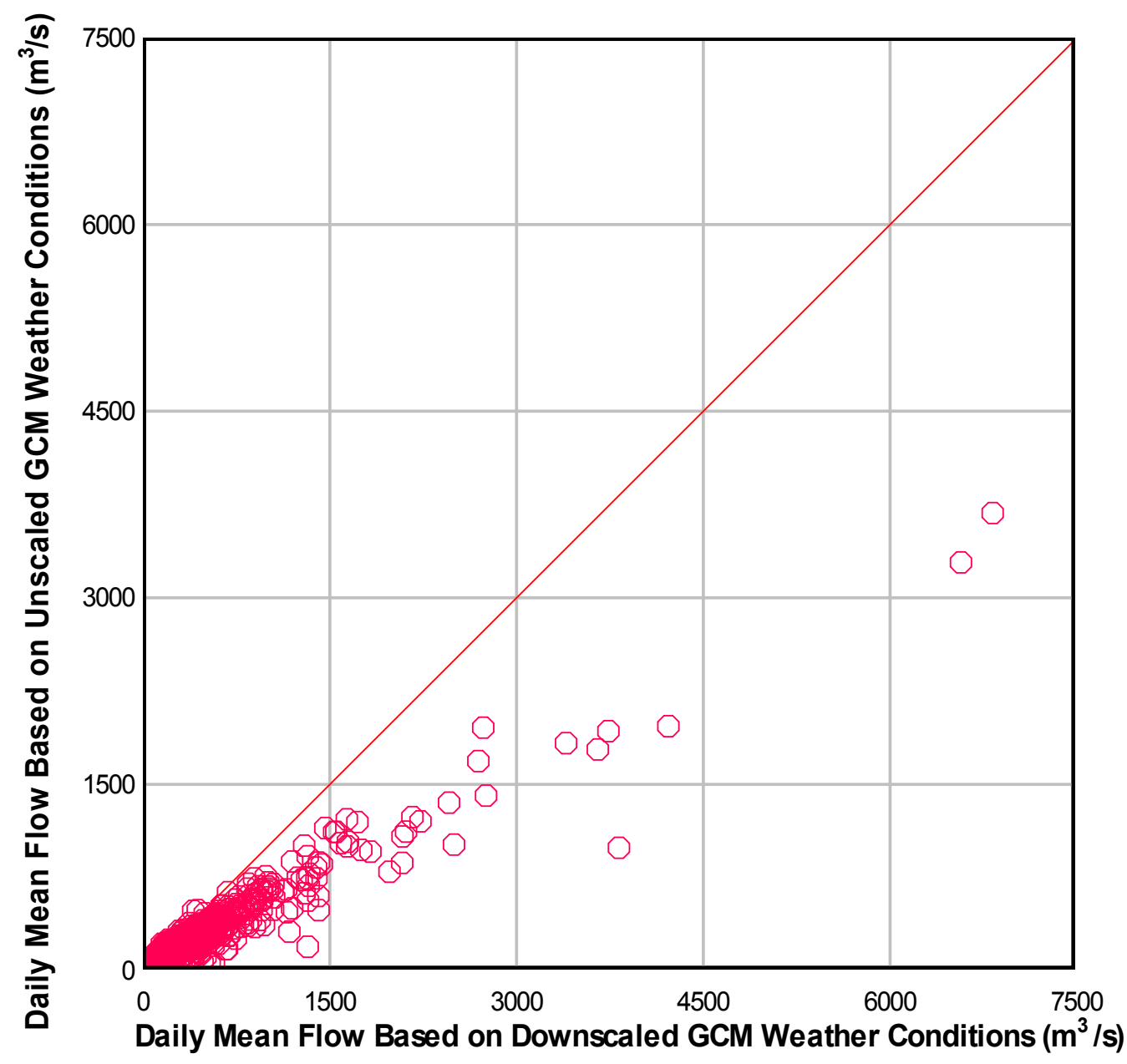


SRNL-STI-2011-00651

Revision 0

Figure 23 Downscaled Model Comparison

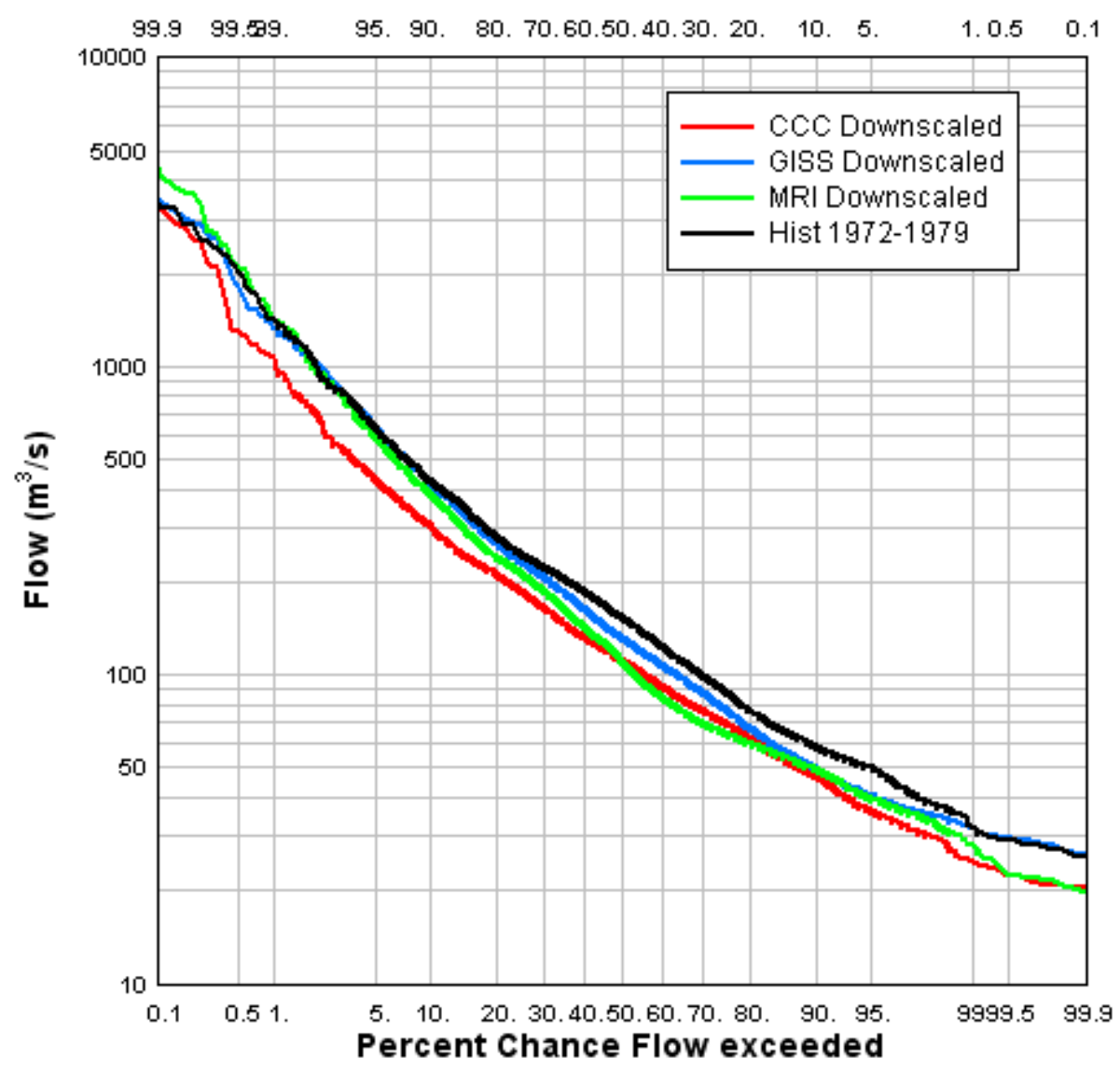


SRNL-STI-2011-00651

Revision 0

Figure 24 Unscaled Model Comparison

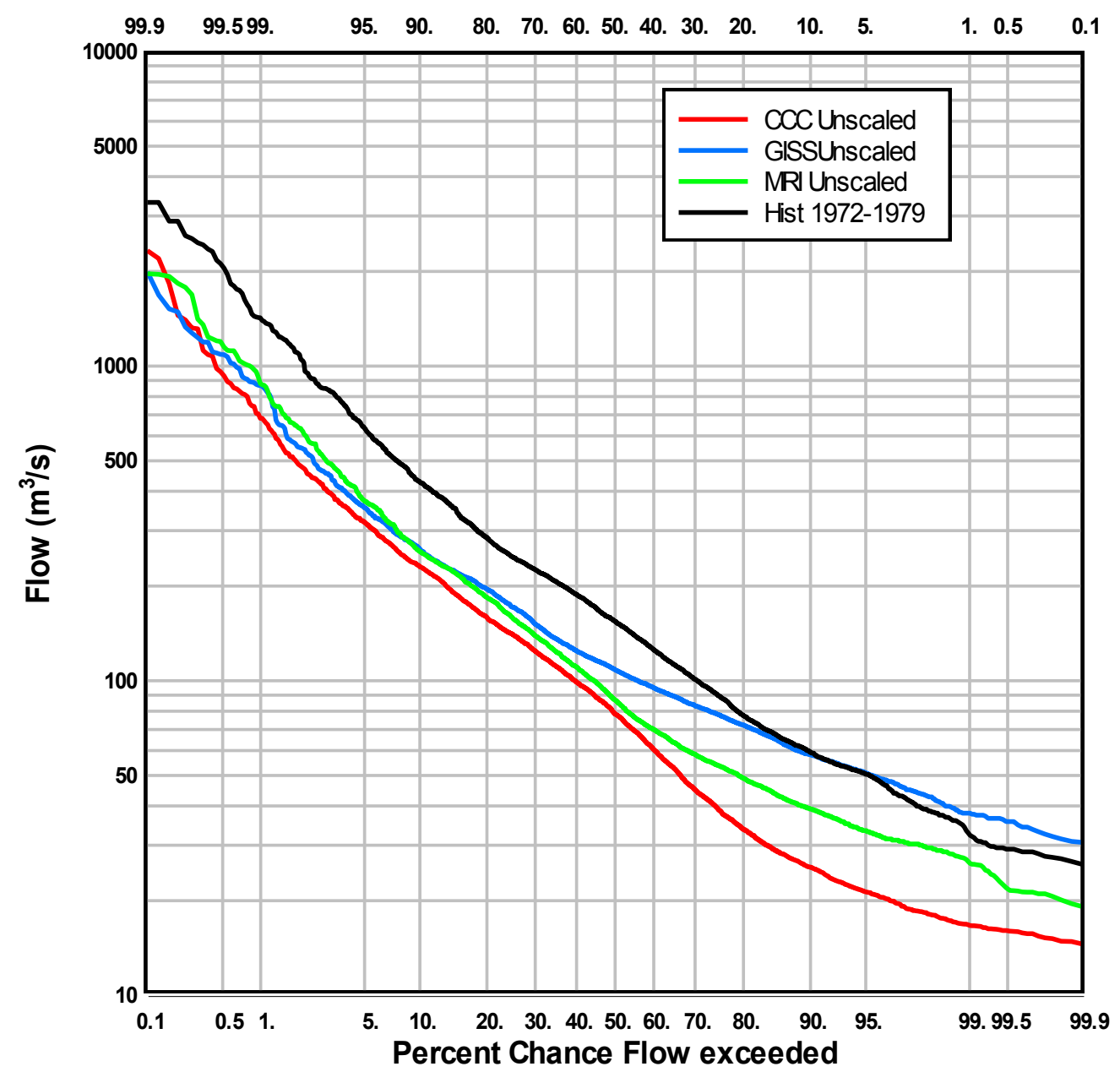


SRNL-STI-2011-00651

Revision 0

Figure 25

Seven-Day Low-Flow Frequency Curve for Coosa River Upstream from Plant Hammond Historical

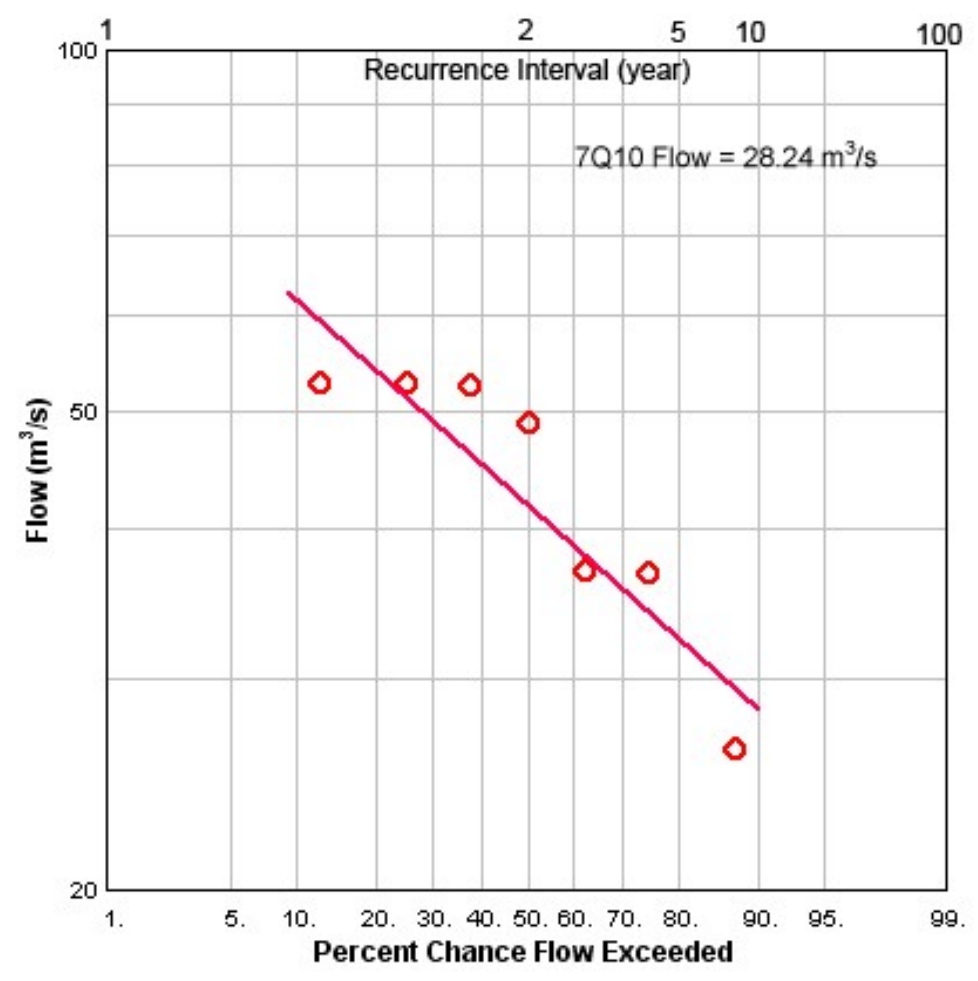


SRNL-STI-2011-00651

Revision 0

Figure 26

Seven-Day Low-Flow Frequency Curve for Coosa River Upstream from Plant Hammond

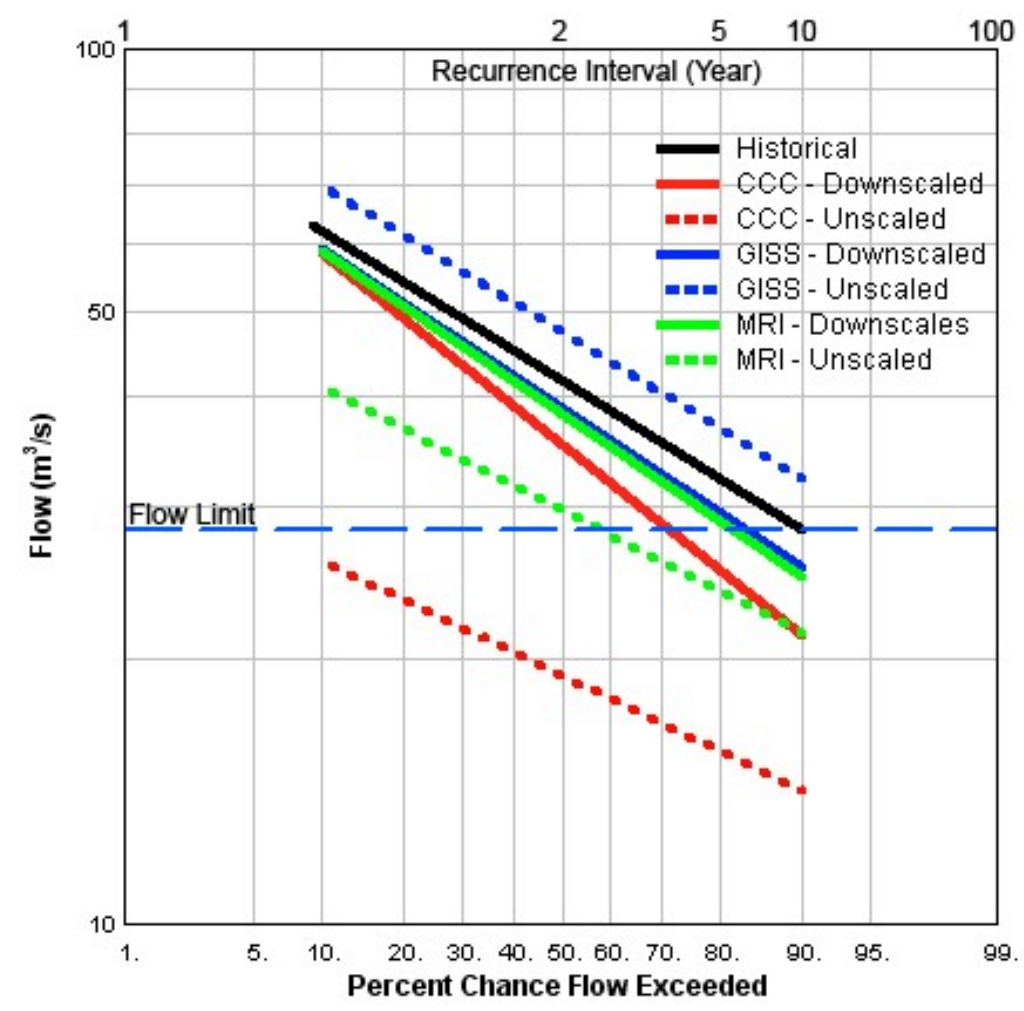




\section{Distribution:}

L. M. Chandler, 773-A

C. H. Hunter, 773-A

R. L. Buckley, 773-A

E. D. Kabela, 773-A

R. J. Kurzeja, 773-A

S. R. Chiswell, 773-A

M. J. Parker, 735-7A

B. J. Viner, 773-A

D. W. Werth, 773-A

Kuo-Fu Chen, 773-A 